\title{
Explicit modeling of organic chemistry and secondary organic aerosol partitioning for Mexico City and its outflow plume
}

\author{
J. Lee-Taylor ${ }^{1}$, S. Madronich ${ }^{1}$, B. Aumont ${ }^{2}$, A. Baker ${ }^{3, *}$, M. Camredon ${ }^{2}$, A. Hodzic ${ }^{1}$, G. S. Tyndall ${ }^{1}$, E. Apel ${ }^{1}$, and \\ R. A. Zaveri $^{4}$ \\ ${ }^{1}$ National Center for Atmospheric Research, Boulder, Colorado, USA \\ ${ }^{2}$ LISA, UMR CNRS 7583, Université Paris Est Créteil et Université Paris Diderot, Créteil, France \\ ${ }^{3}$ University of California, Irvine, CA, USA \\ ${ }^{4}$ Pacific Northwest National Laboratory, Richland, Washington, USA \\ *now at: Max Planck Institute for Chemistry, Mainz, Germany
}

Received: 26 May 2011 - Published in Atmos. Chem. Phys. Discuss.: 20 June 2011

Revised: 12 November 2011 - Accepted: 9 December 2011 - Published: 21 December 2011

\begin{abstract}
The evolution of organic aerosols (OA) in Mexico City and its outflow is investigated with the nearly explicit gas phase photochemistry model GECKO-A (Generator of Explicit Chemistry and Kinetics of Organics in the Atmosphere), wherein precursor hydrocarbons are oxidized to numerous intermediate species for which vapor pressures are computed and used to determine gas/particle partitioning in a chemical box model. Precursor emissions included observed C3-10 alkanes, alkenes, and light aromatics, as well as larger $n$-alkanes (up to C25) not directly observed but estimated by scaling to particulate emissions according to their volatility. Conditions were selected for comparison with observations made in March 2006 (MILAGRO). The model successfully reproduces the magnitude and diurnal shape for both primary (POA) and secondary (SOA) organic aerosols, with POA peaking in the early morning at $15-20 \mu \mathrm{g} \mathrm{m}^{-3}$, and SOA peaking at $10-15 \mu \mathrm{g} \mathrm{m}^{-3}$ during mid-day. The majority $(\geq 75 \%)$ of the model SOA stems from reaction products of the large $n$-alkanes, used here as surrogates for all emitted hydrocarbons of similar volatility, with the remaining SOA originating mostly from the light aromatics. Simulated OA elemental composition reproduces observed $\mathrm{H} / \mathrm{C}$ and $\mathrm{O} / \mathrm{C}$ ratios reasonably well, although modeled ratios develop more slowly than observations suggest. SOA chemical composition is initially dominated by $\delta$-hydroxy ketones and nitrates from the large alkanes, with contributions from peroxy acyl nitrates and, at later times when NOx is lower, organic hydroperoxides. The simulated plume-integrated OA
\end{abstract}

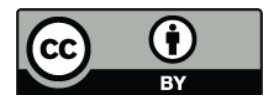

Correspondence to: J. Lee-Taylor (julial@ucar.edu) mass continues to increase for several days downwind despite dilution-induced particle evaporation, since oxidation chemistry leading to SOA formation remains strong. In this model, the plume SOA burden several days downwind exceeds that leaving the city by a factor of $>3$. These results suggest significant regional radiative impacts of SOA.

\section{Introduction}

Aerosols are major constituents of the troposphere, with effects on human health (Pope and Dockery, 2006), urban and regional photochemistry (Jacobson, 1999), precipitation patterns (Rosenfeld et al., 2008), and directly or indirectly on climate (Kanakidou et al., 2005; Forster et al., 2007). Air samples collected in diverse environments show that the mass of organic aerosols (OA) often exceeds that of aerosol sulfate, nitrate, and soot combined (Zhang et al., 2007; Jimenez et al., 2009). OA mass concentrations can vary from $<1 \mu \mathrm{g} \mathrm{m}^{-3}$ in the remote atmosphere (e.g. Coe et al., 2006) to $>70 \mu \mathrm{g} \mathrm{m}^{-3}$ in highly polluted locations such as Beijing (Sun et al., 2010). Atmospheric OA contains a great variety of different chemical compounds (e.g. Ketseridis et al., 1976; Middlebrook et al., 1998; Hamilton et al., 2004). The organic constituents may be grouped into two broad categories, primary and secondary (e.g. Finlayson-Pitts and Pitts, 2000). Primary organic aerosol (POA) results from both direct emissions of particles, and partitioning between the gas and particle phases of unreacted (i.e. primary) partially volatile organic emissions (Donahue et al., 2006). Secondary organic aerosol (SOA) comprises photo-oxidation products of hydrocarbons, of both anthropogenic and biogenic origins (e.g.

Published by Copernicus Publications on behalf of the European Geosciences Union. 
Heisler and Friedlander, 1977; Pandis et al., 1991; Turpin et al., 1991; Pandis et al., 1992; Griffin et al., 1999; Aumont et al., 2000; Claeys et al., 2004; Goldstein and Galbally, 2007; de Gouw and Jimenez, 2009; and works therein). Instrumental techniques distinguish between two main types of organic aerosol; minimally oxygenated "HOA" and highly oxygenated "OOA", usually interpreted as analogues for POA and SOA, respectively. Field observations show that OOA mass generally outweighs HOA mass even in urban source regions (Zhang et al., 2007), and that OOA mass dominance increases downwind and regionally as OA ages and photochemistry progresses (e.g. de Gouw et al., 2008; Zhang et al., 2007). The implied dominance of SOA in the OA budget calls for a deeper understanding of the chemical and physical processes involved in its formation and evolution, as complex as they may be, to enable and improve prediction of OA and its many influences on the atmosphere.

Implementation of SOA in atmospheric models is still in its infancy. Early model parameterizations attempted to describe SOA formation by applying aerosol yields from chamber studies, such as those of Odum et al. (1996), Griffin et al. (1999), Pankow et al. (2001), Jang and Kamens (1999), and Kroll et al. (2005) to observations of reactive organic gases. Results, whether in remote or polluted areas, fell short by $0.5-2$ orders of magnitude, (e.g. Heald et al., 2005; Volkamer et al., 2006). More recently, some improved agreement has been obtained by considering the pool of partly volatile, relatively large hydrocarbons, e.g. in the $\mathrm{C} 11-\mathrm{C} 25$ range, that are not measured as routinely as those $\mathrm{C} 10$ or smaller. Robinson et al. (2007) subdivide these according to vapor pressure in decadal steps (the volatility basis set, VBS), followed by an additional decade drop in vapor pressure each time a molecule is oxidized, e.g. by $\mathrm{OH}$. Refinements on these parameters have been proposed (Grieshop et al., 2009), and may depend on conditions. The VBS approach has been implemented for Mexico City in box models by Dzepina et al. (2009) and in three-dimensional chemistry-transport models (CTMs) by Tsimpidi et al. (2010), Hodzic et al. (2010a), and $\mathrm{Li}$ et al. (2011). These studies yielded aerosol mass concentrations that are larger and more consistent with observations than in previous parameterizations. In the VBS approach, the initial volatility distribution is taken from laboratory dilution experiments on diesel exhaust (Robinson et al., 2007), and the total mass is scaled to either observed POA concentrations, or POA emissions inventory with multiplicative factors that often approach an order of magnitude. The success of these models supports the hypothesis that semiand intermediately-volatile organic compounds (S/IVOCs) are major precursors of SOA in Mexico City, and points to the need to better understand their chemistry.

Here, we consider the explicit gas-phase chemistry of $n$ alkanes leading to condensable and partly oxidized intermediates. The alkanes have long been recognized as important in Mexico City (Blake and Rowland, 1995; Apel et al., 2010). We explore the chemical diversity of SOA and the potential role of alkanes in SOA formation, using the explicit gas phase chemistry model GECKO-A (Aumont et al., 2005). This model predicts the chemical identity of many thousands of reaction products through multiple generations of chemistry, as well as their properties relevant to gas/particle partitioning. We apply the explicit model to a case study of SOA formation in Mexico City and its outflow plume, expanding upon the VBS study of Hodzic et al. (2010a). The Mexico City region was studied in the March 2006 MILAGRO field campaign (Molina et al., 2010). A wide range of aerosol characteristics was observed in MILAGRO, including aerosol mass concentrations (Aiken et al., 2009), atomic ratios (oxygen and nitrogen to carbon ratios) (Aiken et al., 2008), presence of specific functional groups (Liu et al., 2009), and formation rates (Kleinman et al., 2008). We evaluate our model in Sect. 3 of this work by comparing with observations. In Sect. 4 we place the results in context, discussing uncertainties and model limitations, and highlighting areas where further research is needed to improve our understanding of chemistry leading to SOA formation.

\section{Model description}

\subsection{The chemical mechanism generator}

This study uses a chemical mechanism generator model in combination with a 0-D chemical box model. The chemical mechanism generator GECKO-A (Generator of Explicit Chemistry and Kinetics of Organics in the Atmosphere) was described in detail by Aumont et al. (2005) with updates by Camredon et al. (2007) and Aumont et al. (2008). In brief, the model gives a nearly explicit representation of the chemistry of aliphatic compounds via structure-activity relationships. Such relationships are not easily predicted for aromatic compounds, so the chemistry for these species is taken from the Leeds MCM V3.1 mechanism (Bloss et al., 2005a) until aliphatic products are generated. Saturation vapor pressures of all non-radical species in the mechanism are computed using the method of Myrdal and Yalkowsky (1997) with boiling points estimated using the group contribution method of Joback and Reid (1987). The group contributions used for the hydroperoxide and nitrate moieties are as specified in Camredon and Aumont (2006). Equilibrium gas-aerosol partitioning (Pankow, 1994a) is computed using Raoult's law, iterated each timestep over the list of all condensing species to account for the influence of each species on the total aerosol mass, and until the particle-phase concentrations of all species change by $<0.1 \%$ between iterations. This model configuration assumes an instantaneously well-mixed aerosol phase of undefined particle size. Activity coefficients are assumed to equal unity. No in-aerosol chemistry or surface effects are considered. 
Table 1. Initial (midnight) values of inorganics, OVOCs and selected VOCs defined in the Mexico City box model.

\begin{tabular}{llll}
\hline \multirow{2}{*}{ Species } & \multicolumn{2}{c}{$\begin{array}{c}\text { Initial mixing } \\
\text { ratio (ppbv) }\end{array}$} & \\
\cline { 2 - 3 } & $\begin{array}{l}\text { Boundary } \\
\text { layer }\end{array}$ & Background & \\
\hline $\mathrm{O}_{3}$ & 15 & 50 & $\mathrm{R} ; \mathrm{T}$ \\
$\mathrm{NO}_{\mathrm{x}}\left(\right.$ as $\left.\mathrm{NO}_{2}\right)$ & 50 & 0.1 & $\mathrm{R} ; \mathrm{S}$ \\
$\mathrm{HONO}$ & 1.4 & 0 & $\mathrm{~L} ; \mathrm{E}$ \\
$\mathrm{CO}$ & 963 & 126 & $\mathrm{E} ; \mathrm{E}$ \\
$\mathrm{CH}$ & 2030 & 2050 & $\mathrm{~A} ; \mathrm{E}$ \\
Formaldehyde (methanal) & 10 & 0.5 & $\mathrm{D} ; \mathrm{E}$ \\
Methanol & 53 & 0.5 & $\mathrm{~F} ; \mathrm{E}$ \\
Acetaldehyde (ethanal) & 7.5 & 0 & $\mathrm{~F}$ \\
Acetone (propanone) & 14 & 0 & $\mathrm{~F}$ \\
Propanal & 2.0 & 0 & $\mathrm{E}$ \\
Methacrolein & 2.4 & 0 & $\mathrm{~F}$ \\
Methyl vinyl ketone & 2.4 & 0 & $\mathrm{~F}$ \\
Ethyl acetate & 8 & 0 & $\mathrm{~F}$ \\
Ethyne & 8.3 & 0 & $\mathrm{~A}$ \\
Isoprene & 0.26 & 0 & $\mathrm{~A}$ \\
Methylcyclopentane & 0.60 & 0 & $\mathrm{~A}$ \\
\hline
\end{tabular}

A Median urban values, Apel et al. (2010); ${ }^{\mathrm{E}}$ Estimate; ${ }^{\mathrm{F}}$ Mean daytime values at T0, Fortner et al. (2009); ${ }^{\mathrm{L}} \mathrm{Li}$ et al. (2010); ${ }^{\mathrm{R}}$ Midnight citywide monthly mean (Sistema de Monitoreo Atmosférico, SIMAT, http://www.sma.df.gob.mx/simat2/); ${ }^{\mathrm{S}}$ Minimum value of Shon et al. (2008); ${ }^{\mathrm{T}}$ Thompson et al. (2008).

Chemical mechanisms generated using GECKO-A can be extremely large with millions of chemical species and reactions, complicating their implementation in even a simple box model such as is used here. Two sets of assumptions are made routinely to reduce mechanism size (Valorso et al., 2011). First, species with vapor pressures below $10^{-13} \mathrm{~atm}$ are assumed to partition exclusively to the particle phase. They are thus removed from the gas phase scheme and generate no further products. Next, some longer-chain species are lumped into chemically similar isomers, according to a hierarchical decision tree based on molecular structure (Aumont et al., 2008). Without these two assumptions, the number of species in a mechanism containing only $n$-alkanes increases by almost an order of magnitude for each new carbon added to the alkane (Aumont et al., 2005). Implementing both assumptions reduces the mechanism to a manageable size (with fewer than one million species for any single $n$-alkane oxidation mechanism), without introducing significant error in box-model simulated ozone and SOA mass (Valorso et al., 2011) relative to the comparable fully-explicit mechanism (Aumont et al., 2008).

The inorganic species and primary non-methane hydrocarbons (NMHCs) represented in our simulations are listed in Tables 1,2, and 3. We apply an additional assumption to control mechanism size, by restricting the number of successive generations of oxidation undergone by the longestchain NMHCs. A generation is defined as a sequence of reactions that begins and ends with a non-radical species.
Nonadecane and eicosane $\left(\mathrm{C}_{19}\right.$ and $\left.\mathrm{C}_{20}\right)$ were allowed to react through five generations, while larger NMHCs were restricted to three generations of chemistry. A sensitivity test showed these assumptions to have negligible impact on modeled gas/aerosol partitioning. Species were addressed in order of increasing carbon number and structural complexity, so that the chemistry of previously-identified fragmentation products was not restricted. The GECKO-A chemical reaction mechanism generated from these precursor species consists of almost 6 million reactions among 1.1 million unique chemical species, including 0.28 million organic non-radical species.

\subsection{Box model: meteorological description}

The explicit chemical mechanism is implemented in a 0 D (box) model which employs a two-step solver (Verwer, 1994; Verwer et al., 1996) with variable timestep. Diurnally varying photolysis frequencies are calculated using the TUV (tropospheric ultraviolet-visible) radiative transfer model (Madronich and Flocke, 1997), and reduced by $20 \%$ to approximate attenuation of incoming solar radiation by tropospheric aerosols (Castro et al., 2001; Corr et al., 2009). For the present study, the model was driven with diurnallyvarying meteorological boundary conditions representative of the average situation in Mexico City during March 2006. The box model calculates the rate of change with time, $t$, of a gas-phase chemical species $A$ as follows:

$$
\begin{aligned}
& \frac{d[A]}{d t}=P_{\text {chem }}-L_{\text {chem }}+ \\
& P_{\text {emis }} / z-k_{\text {dep }}[A]-k_{\text {vent }}\left([A]-\left[A_{\text {bg }}\right]\right)-k_{\text {ent }}\left([A]-\left[A_{\mathrm{ft}}\right]\right)(1)
\end{aligned}
$$

where $[A]$ is the concentration, in units of molecules $\mathrm{m}^{-3}$, and subscripts bg and $\mathrm{ft}$ denote values for background and free troposphere air respectively. $P_{\text {chem }}$ and $L_{\text {chem }}$ are the rates of production and loss with respect to both photochemistry and gas-aerosol partitioning (with units of molecules $\mathrm{m}^{-3} \mathrm{~s}^{-1}$ ), and $P_{\mathrm{emis}}$ is the emissions rate (molecules $\mathrm{m}^{-2} \mathrm{~s}^{-1}$ ). Boundary layer heights, $z$, were based on the observations of Shaw et al. (2007), with the overnight boundary layer height fixed at $250 \mathrm{~m}$. $k_{\mathrm{dep}}, k_{\mathrm{vent}}$ and $k_{\mathrm{ent}}$ (units s ${ }^{-1}$ ) are the first-order rate coefficients of depositional loss, ventilation (lateral exchange with the background atmosphere via advection and mechanical mixing) and entrainment (vertical exchange with the free troposphere as the boundary layer height increases):

$k_{\text {ent }}=\max \left\{\frac{d \ln z}{d t}, 0\right\}$

The assumption implicit in the box model of rapid mixing within the boundary layer is supported by observations showing no altitude dependence of $\mathrm{O}_{3}$ or particulate matter (e.g. de Foy et al., 2006; Greenberg et al., 2009). Diurnally varying ventilation rate coefficients, $k_{\text {vent }}$, (Fig. 1), were estimated from wind speeds collected at 15 sites of the Ambient 
Table 2. NMHCs measured ${ }^{\mathrm{a}}$ in Mexico City and included as emissions in the model. Background values for each species were assumed to be zero.

\begin{tabular}{|c|c|c|c|c|}
\hline \multirow[t]{2}{*}{$\begin{array}{l}\text { Species } \\
\text { name }\end{array}$} & \multicolumn{2}{|c|}{$\begin{array}{l}\text { Measured concentrations } \\
\text { (pptv) }\end{array}$} & \multicolumn{2}{|c|}{$\begin{array}{l}\text { Modeled emissions } \\
\left(10^{9} \text { molec } \mathrm{cm}^{-2} \mathrm{~s}^{-1}\right)\end{array}$} \\
\hline & $\begin{array}{r}\text { Citywide } \\
24 \mathrm{~h}^{\mathrm{b}}\end{array}$ & $\begin{array}{r}\text { T0 } \\
\text { daytime }^{\mathrm{c}}\end{array}$ & Group $^{d}$ & $\begin{array}{r}\text { Noon emission } \\
\text { rate }\end{array}$ \\
\hline Ethane & 5101 & 6447 & ETH & 1900 \\
\hline Propane & 30809 & 37536 & $\mathrm{HC} 3$ & 12900 \\
\hline$n$-Butane & 12569 & 20332 & $\mathrm{HC} 3$ & 6980 \\
\hline$i$-Butane & 4221 & 8266 & $\mathrm{HC} 3$ & 2840 \\
\hline 2,2-Dimethylbutane & 469 & 656 & $\mathrm{HC} 3$ & 225 \\
\hline$i$-Pentane & 4555 & 8380 & HC5 & 2950 \\
\hline$n$-Pentane & 3012 & 5016 & HC5 & 1770 \\
\hline$n$-Hexane & 1628 & 4493 & HC5 & 1580 \\
\hline 2,3-Dimethylbutane & 2550 & 2959 & HC5 & 1040 \\
\hline 2-Methylpentane & 1919 & 2894 & HC5 & 1020 \\
\hline 3-Methylpentane & 1324 & 2057 & HC5 & 724 \\
\hline 2,2,4-Trimethylpentane & 718 & 1045 & $\mathrm{HC} 5$ & 118 \\
\hline$n$-Heptane & 367 & 679 & $\mathrm{HC} 5$ & 239 \\
\hline Cyclopentane & 251 & 365 & HC5 & 128 \\
\hline 2,3,4-Trimethylpentane & 286 & 335 & $\mathrm{HC} 5$ & 28 \\
\hline 2,4-Dimethylpentane & 198 & 301 & HC5 & 368 \\
\hline Cyclohexane & 235 & 301 & HC8 & 176 \\
\hline$n$-Octane & 154 & 245 & $\mathrm{HC} 8$ & 136 \\
\hline Decane & 154 & 224 & $\mathrm{HC} 8$ & 124 \\
\hline$n$-Nonane & 102 & 123 & $\mathrm{HC} 8$ & 68 \\
\hline Ethene & 6908 & 7808 & OL2 & 3480 \\
\hline Propene & 1756 & 1765 & OLT & 1320 \\
\hline 1-Butene $+i$-Butene & 880 & 1022 & OLT & 762 \\
\hline 1-Pentene & 101 & 264 & OLT & 197 \\
\hline 3-Methyl-1-butene & 58 & 126 & OLT & 94 \\
\hline 1,3-Butadiene & 152 & 122 & OLT & 91 \\
\hline 2-Methyl-2-butene & 219 & 606 & OLI & 718 \\
\hline trans+cis-2-Butene $\mathrm{e}^{\mathrm{e}}$ & 249 & 770 & OLI & 499 \\
\hline trans+cis-2-Pentene $\mathrm{e}^{\mathrm{e}}$ & 243 & 546 & OLI & 185 \\
\hline Toluene & 8944 & 10649 & TOL & 3640 \\
\hline Benzene & 931 & 1703 & TOL & 581 \\
\hline Ethylbenzene & 532 & 938 & TOL & 320 \\
\hline$m$-Xylene & 452 & 845 & XYL & 745 \\
\hline 1,2,4-Trimethylbenzene & 434 & 834 & XYL & 735 \\
\hline$o$-Xylene & 238 & 404 & XYL & 356 \\
\hline$p$-Xylene & 180 & 373 & XYL & 329 \\
\hline 3-Ethyltoluene & 118 & 244 & XYL & 215 \\
\hline 4-Ethyltoluene & 68 & 138 & XYL & 122 \\
\hline 1,3,5-Trimethylbenzene & 70 & 115 & XYL & 101 \\
\hline 2-Ethyltoluene & 52 & 108 & XYL & 95 \\
\hline
\end{tabular}

${ }^{a}$ Measured values are from Apel et al. (2010), unless otherwise noted, ${ }^{b}$ values also used as model initial concentrations, ${ }^{c}$ values used to apportion model emissions, ${ }^{\mathrm{d}}$ emission groups are defined as per the RACM mechanism (Stockwell et al., 1997), ${ }^{\mathrm{e}}$ no distinction is made in the model between trans- and cis- isomers.

Air Monitoring Network (Red de Meteorología y Radiación Solar, REDMET, available online, http://www.smadf.gob. $\mathrm{mx} /$ simat2/). Hourly wind speed values were averaged over the entire month on an hourly basis first by city sector and then over the city, giving mean values varying from $1 \mathrm{~m} \mathrm{~s}^{-1}$ at night to $3.3 \mathrm{~m} \mathrm{~s}^{-1}$ during mid-afternoon. These values were converted to dilution rate coefficients by division over the $40 \mathrm{~km}$ city length scale. Wet and dry deposition were neglected. The Mexico City region was generally dry for much of March 2006 (Fast et al., 2007), hence wet deposition may 
Table 3. Assignment of emissions of longer-chain $n$-alkanes used as surrogates for all unmeasured NMHCs.

\begin{tabular}{rlllr}
\hline $\begin{array}{r}\text { Carbon } \\
\#\end{array}$ & $\begin{array}{l}\text { Species } \\
\text { name }\end{array}$ & $\begin{array}{l}C^{*} 298 \mathrm{~K} \\
\left(\mu \mathrm{g} \mathrm{m}^{-3}\right)\end{array}$ & $\begin{array}{l}\text { Volatility } \\
\text { bin }^{\mathrm{a}}\end{array}$ & $\begin{array}{r}\text { Noon emission rate } \\
\left(10^{9} \mathrm{molec}^{-2} \mathrm{~s}^{-1}\right)\end{array}$ \\
\hline 11 & $n$-undecane & $7 \times 10^{6}$ & None & 210 \\
12 & $n$-dodecane & $2 \times 10^{6}$ & $\mathrm{IVOC}_{3}$ & 185 \\
13 & $n$-tridecane & $7 \times 10^{5}$ & $\mathrm{IVOC}_{3}$ & 171 \\
14 & $n$-tetradecane & $2 \times 10^{5}$ & $\mathrm{IVOC}_{2}$ & 99 \\
15 & $n$-pentadecane & $5 \times 10^{4}$ & $\mathrm{IVOC}_{2}$ & 92 \\
16 & $n$-hexadecane & $1.3 \times 10^{4}$ & $\mathrm{IVOC}_{1}^{\mathrm{b}}$ & 92 \\
17 & $n$-heptadecane & $3 \times 10^{3}$ & $\mathrm{IVOC}_{1}^{\mathrm{b}}$, SVOC $_{6}$ & 76 \\
18 & $n$-octadecane & $7 \times 10^{2}$ & $\mathrm{SVOC}_{6}$ & 62 \\
19 & $n$-nonadecane & $1.5 \times 10^{2}$ & SVOC $_{5}$ & 35 \\
20 & $n$-eicosane & $3 \times 10^{1}$ & SVOC $_{5}$, SVOC $_{4}$ & 30 \\
21 & $n$-henicosane & $6 \times 10^{0}$ & SVOC $_{4}$ & 25 \\
22 & $n$-docosane & $1 \times 10^{0}$ & SVOC $_{3}$ & 23 \\
23 & $n$-tricosane & $2 \times 10^{-1}$ & SVOC $_{2}$ & 9.6 \\
24 & $n$-tetracosane & $3 \times 10^{-2}$ & SVOC $_{2}$, SVOC $_{1}$ & 4.9 \\
25 & $n$-pentacosane & $5 \times 10^{-3}$ & SVOC $_{1}$ & \\
\hline
\end{tabular}

a Bin definitions correspond to those used by Hodzic et al. (2010a), b bin "IVOC 1 " was designated "IVOC 1 + SVOC $_{7}$ " by Hodzic et al. (2010a).

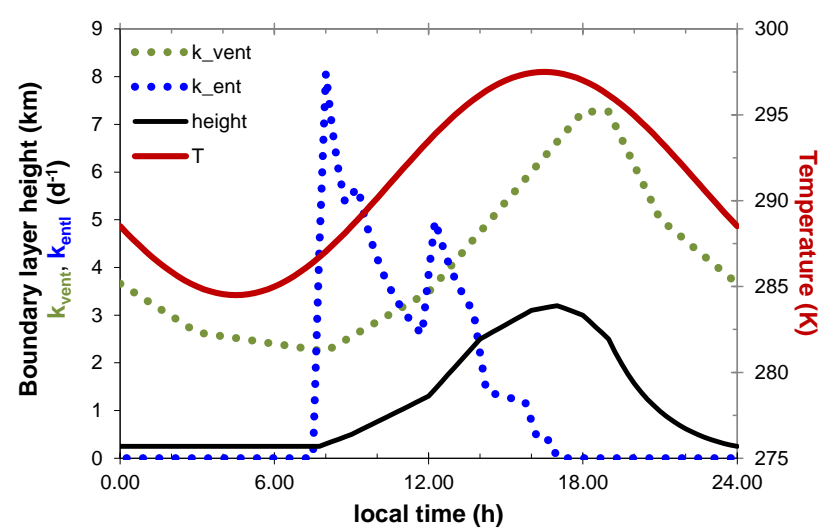

Fig. 1. Meteorological parameters prescribed in the box model Eulerian simulations. Solid lines show boundary layer height $(\mathrm{km}$, black, left axis) and temperature (K, red, right axis). Dotted lines show $k_{\text {ent }}$, the first-order rate of entrainment, i.e. vertical incorporation of free tropospheric air due to increasing boundary layer depth (expressed in units of $\mathrm{day}^{-1}$, blue, left axis), and $k_{\mathrm{vent}}$, the firstorder rate of ventilation, i.e. lateral exchange with background air due to advection and mechanical mixing (in units of day ${ }^{-1}$, green, left axis).

reasonably be omitted. Dry deposition may have some effect on our results, with removal rates of order of a day for the most labile compounds (e.g., $\mathrm{HNO}_{3}$ with a deposition velocity of $3 \mathrm{~cm} \mathrm{~s}^{-1}$ in a $2 \mathrm{~km}$ boundary layer) and could become important in multiday simulations if the air parcel remains in contact with the ground. In any case, parameters for dry deposition of SOA and its precursors are poorly known.
City center ambient surface temperatures (REDMET, reference as above) were approximated as a sine function about $291 \mathrm{~K}$, with a diurnally repeating peak-to-peak amplitude of 13K, maximizing at 16:30 local time (CST). Times will be expressed in CST throughout this work. We find that over $24 \mathrm{~h}>99 \%$ of an inert tracer is flushed from the box model by advection and entrainment, indicating that a one-day spinup period is sufficient for the emissions and chemistry to reach steady state. Prescribed meteorological conditions are summarized in Fig. 1.

Two different scenarios are modeled. The Eulerian run represents the situation in the city, with meteorological parameters and emissions profiles repeated on a daily basis. The Lagrangian run represents the evolution of an air parcel in a model Mexico City outflow plume and was started at 15:00, using output from the Eulerian simulation as initial conditions. To simulate a free-floating air parcel, $P_{\text {emis }}$ and $k_{\text {ent }}$ were set to zero, and $k_{\mathrm{vent}}$ was replaced with $k_{\mathrm{dil}}$, the rate of dilution with background air, with a nominal value of $1 \mathrm{day}^{-1}$. The diurnal temperature cycle was kept the same as for the Eulerian run to simplify the interpretation of the box model results, although different temperature evolution could also be envisioned. Model output was obtained at $15 \mathrm{~min}$ resolution.

\subsection{Box model: chemical initialisation and emissions}

Initial conditions and emission rates for inorganic and primary organic species represented in our simulations are listed in Tables 1, 2, and 3. Where measurements exist, NMHC concentrations were initialised using 24-h citywide mean 


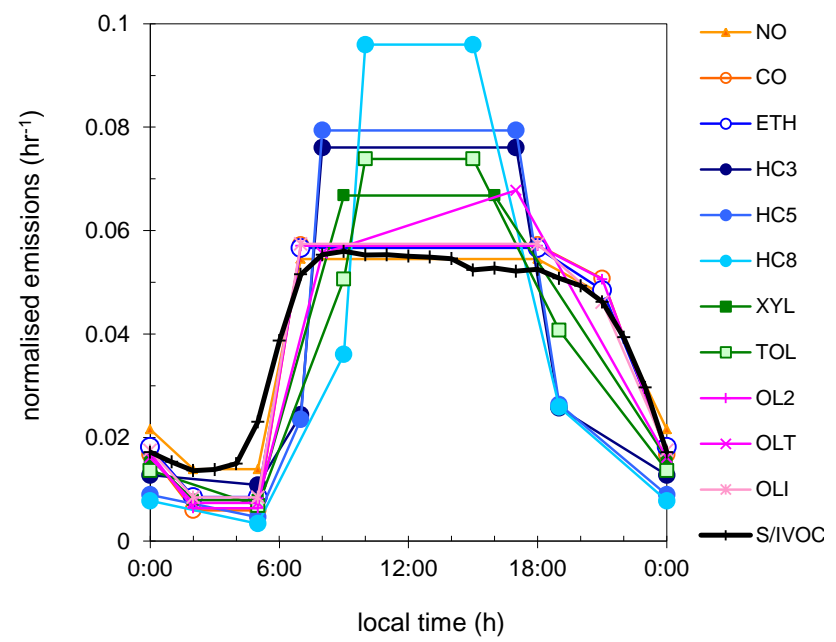

Fig. 2. Diurnal cycles of prescribed emission rates, by lumped chemical group (see Table 2 for group names and constituents). Emissions are normalized in this figure such that the daily sum of the hourly emissions for each species is unity. The model interpolates linearly between input data points (indicated by symbols).

observations from Mexico City (Apel et al., 2010). Background and free troposphere concentrations of NMHCs not listed in Table 1 were assumed to be negligible for the purposes of the present study. Emissions of species listed in Table 2, and of CO and NO, were based on the emissions inventory and diurnal patterns for Mexico City used by Tie et al. (2009) in the WRF-Chem model, see Fig. 2. WRFChem lumps chemical species based on their reactivity, as per the RACM mechanism of Stockwell et al. (1997). We estimated emissions of individual species by first assigning each of the primary NMHCs in our simulation to a lumped group according to its chemical characteristics including $\mathrm{OH}$ reaction rate. We then assigned emissions rates of the various species within a group in proportion to their relative abundances in the mean daytime observations from the MIRAGE urban background measurement site T0 (Instituto Mexicano del Petroleo) (see Table 2 of Apel et al., 2010). The total molecular emissions rate for each lumped group was specified as in Tie et al. (2009), except for the HC8 group (comprising of octane, nonane, decane, and cyclohexane) which we reduced by a factor of 5 to allow our modeled mixing ratios to more closely match the observations. Our noontime emission rate for benzene is almost identical to that derived from airborne eddy covariance flux measurements (Karl et al., 2009), while our emission rate for toluene is about $35 \%$ higher.

Organic aerosol is formed in the box model by instantaneous equilibration of partially volatile species between the gas and organic particle phases according to Raoult's Law. We assume ideality, i.e. all activity coefficients are set to unity. In order to initiate condensation to the aerosol of modeled chemical species, we prescribe an ideal nonvolatile organic seed aerosol with a constant concentration of $2 \mu \mathrm{g} \mathrm{m}^{-3}$ and a mean molecular mass of 200 a.m.u. (atomic mass units), based on the estimate of Hodzic et al. (2009) for biogenic and biomass burning-derived aerosol present in the city from the regional background. Halving or doubling the seed aerosol amount changes daytime SOA mass by $< \pm 4 \%$, showing that model daytime SOA is relatively insensitive to the seed amount chosen. NMHCs larger than 10 carbons were not measured during MILAGRO; however, these species are of critical importance since their lower volatility means their reaction products are expected to contribute significantly to SOA (e.g. Robinson et al., 2007). Quantification of emissions of low-volatility species is complicated by their existence in both gas and primary particle phases, and a lack of species-resolved measurements in either phase. Recently, Tsimpidi et al. (2010) and Hodzic et al. (2010a) used volatility-resolved emissions estimates to simulate emission of an unspeciated primary organic mixture. Following the method of Hodzic et al. (2010a), we based our estimate of emissions of semiand intermediately-volatile organic compounds (S/IVOCs) on the Mexico City inventory (CAM, Comision Ambiental Metropolitana, 2006) which has daily POA emissions near the T0 site of $\sim 19 \mathrm{~kg} \mathrm{~km}^{-2} \mathrm{~d}^{-1}$ and diel emissions variation as shown in Fig. 2. Again following Hodzic et al. (2010a), we multiplied the inventory POA emissions by 7.5 to allow for gaseous co-emissions, and divided the resulting mass into bins based on the VBS approach of Robinson et al. (2007). The VBS bins are defined in terms of logarithmic steps in effective saturation concentration $\left(C^{*}\right.$, with units of $\left.\mu \mathrm{g} \mathrm{m}^{-3}\right)$.

The chemical identities of the S/IVOCs emitted in Mexico City are unknown, and therefore it was necessary to specify surrogate species to represent all emitted partially-volatile NMHCs. We use $n$-alkanes for our model surrogate emissions. Alkanes as a class are a major contributor to anthropogenic emissions (Lim and Ziemann, 2005, and references therein). Also, $n$-alkanes provide relatively simple chemical analogs for the many possible branched isomers, which make minor individual contributions to the NMHC atmospheric burden but together contribute a mass comparable to that of $n$-alkanes (Fraser et al., 1997). In principle, branched alkanes may undergo more fragmentation than do $n$-alkanes, especially if the degree of branching is high enough to force fragmentation rather than radical isomerisation. However, since diesel fuel (which will be responsible for the majority of C12-C20 alkanes in Mexico City) is predominantly linear, we assume that the ratio of branching to chain length is sufficiently low that calculated SOA yields will not be significantly affected. For each of the $\mathrm{C}_{11-25} n$-alkanes, we estimated $C^{*}$ at $298 \mathrm{~K}$ via the method of Myrdal and Yalkowsky (1997). We then assigned the $n$ alkane to the appropriate $C^{*}$ bin in the volatility-based emissions mass distribution. In some cases an $n$-alkane was divided between two bins, or two $n$-alkanes were assigned to the same bin. Undecane $\left(\mathrm{C}_{11}\right)$ is too volatile for the topmost 

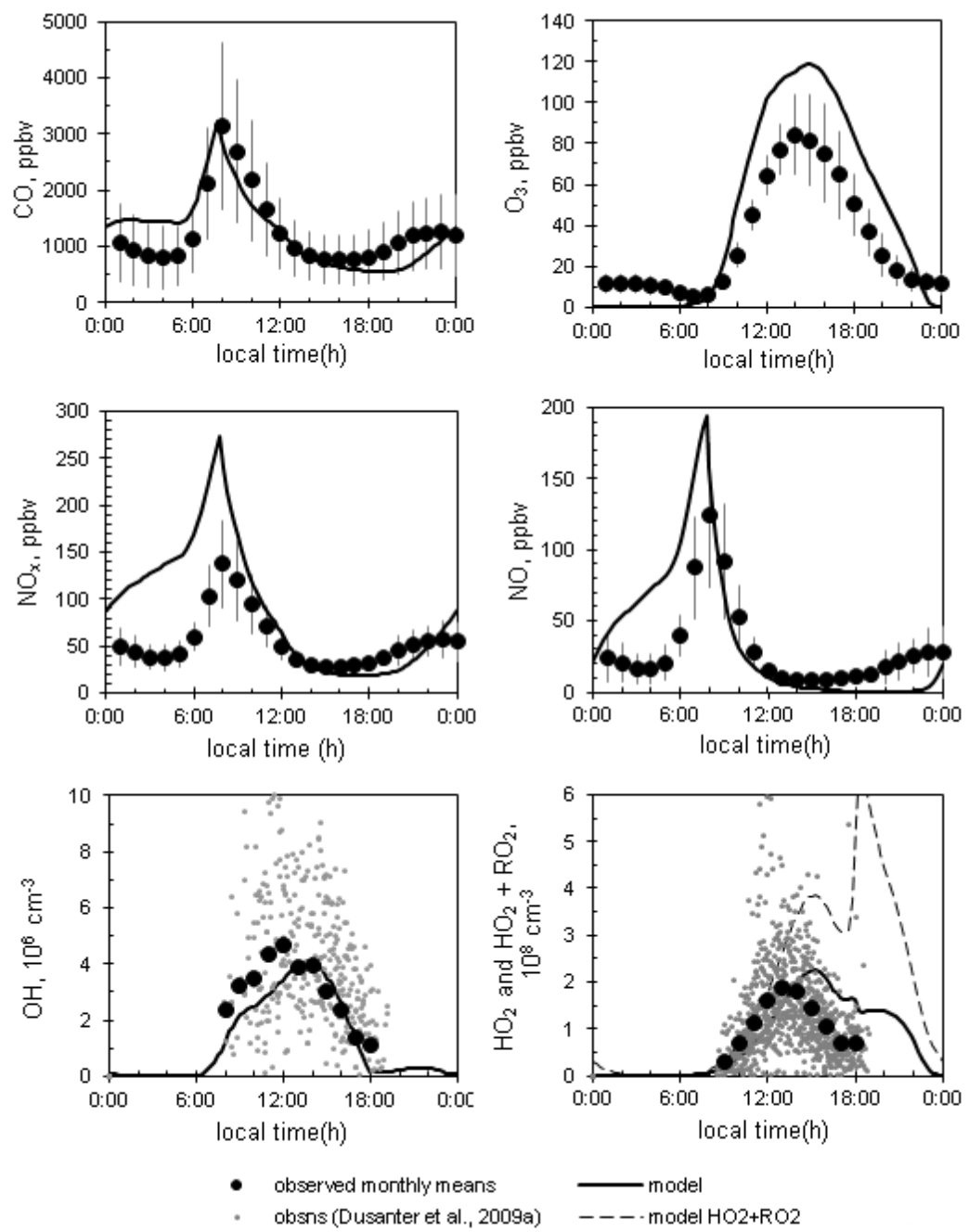

Fig. 3. Modeled diurnal cycles of major inorganic gases in Mexico City during March 2006. Hourly mean observations for $\mathrm{CO}, \mathrm{O}_{3}$, $\mathrm{NO}$ and $\mathrm{NO}_{\mathrm{x}}$ are citywide averages for the entire month, with error bars showing one standard deviation about the mean (SIMAT). Hourly mean observations of $\mathrm{OH}$ and $\mathrm{HO}_{2}$ are from T0 between 14 and 31 March (Dusanter et al., 2009a). No $\mathrm{RO}_{2}$ observations are shown.

bin (IVOC3), so it is treated as a purely gaseous species, with estimated emissions between those of decane $\left(\mathrm{C}_{10}\right)$ and dodecane $\left(\mathrm{C}_{12}\right)$. The resulting $n$-alkane emission rates are given in Table 3. Total estimated S/IVOC emissions were $143 \mathrm{~kg} \mathrm{~km}^{-2} \mathrm{~d}^{-1}$ near the T0 site, as in Hodzic et al. (2010a).

\section{Results}

\subsection{Photochemical environment}

A reasonably accurate gas phase reactivity is pre-requisite for modeling SOA. Figure 3 compares our Eulerian model results for inorganic gases to the monthly means of hourly measurements of $\mathrm{CO}, \mathrm{O}_{3}, \mathrm{NO}$, and $\mathrm{NO}_{\mathrm{x}}$ taken at each of 17 to 22 sites throughout Mexico City (Sistema de Monitoreo Atmosférico, SIMAT, http://www.sma.df.gob.mx/ simat2/, number of sites varies by species), and of $\mathrm{OH}$ and $\mathrm{HO}_{2}$ taken at the T0 site (Dusanter et al., 2009a). Simulated $\mathrm{NO}_{\mathrm{x}}$ matches observations during daytime (generally 09:00 to 18:00), although we overestimate ozone and $\mathrm{NO}_{2}$ while underestimating NO. The ozone-NO-NO $\mathrm{N}_{2}$ system is dynamic with species interconverting on timescales of minutes. The plotted observations, however, represent monthly means over $\sim 20$ measurement stations of hourly averaged ambient concentrations, and thus local scale spatial or temporal heterogeneities are smoothed out. Apparent inconsistencies in the oxidative balance can result as an artifact of data averaging. For example, the average night-time concentrations of NO and $\mathrm{O}_{3}$ cannot be collocated, and only appear as non-zero by averaging locations where one or the other reagent is titrated away. Despite such difficulties in comparisons, the overall oxidation capacity and radical balance of the model atmosphere are in reasonable agreement with measured ranges. 


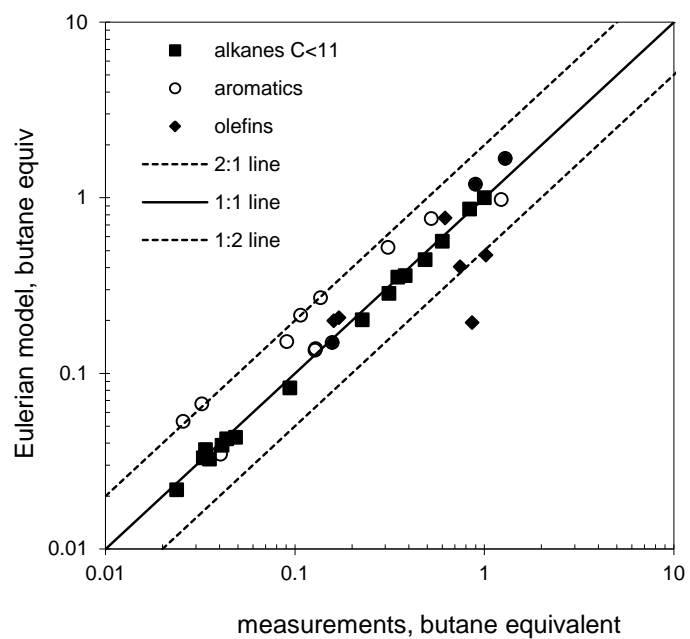

Fig. 4. Comparison between modeled and observed $\mathrm{OH}$ reactivity of the emitted NMHCs within Mexico City, averaged over daytime hours (09:00 to 18:00) and expressed relative to butane.

In common with other models (e.g. Dusanter et al., 2009b), we underestimate the rapid morning rise in $\mathrm{OH}$ and $\mathrm{HO}_{2}$ that results from photolysis of $\mathrm{HONO}$ whose origin is a subject of current research (Li et al., 2010). However, the peak values of both $\mathrm{OH}$ and $\mathrm{HO}_{2}$ are simulated well (see Fig. 3). We simulate a large $\mathrm{RO}_{2}$ spike at sundown concurrent with an evening increase in $\mathrm{NO}_{3}$ (not shown), due to the reaction of $\mathrm{NO}_{3}$ with alkenes and with dioxa-bicyclic oxidation products of aromatic species (Bloss et al., 2005a). Daytime $\mathrm{OH}$ reactivites (i.e. concentration weighted by rate of reaction with $\mathrm{OH}$ ) for the observed NMHCs are presented in Fig. 4. Agreement between our Eulerian simulation results and observations is generally within a factor of two, with the exception of 2-pentene, whose emissions were underrepresented by a factor of 4 . The net $\mathrm{OH}$ reactivity from NMHCs was $97 \%$ of that observed at T0.

Our simulated $\mathrm{C}_{11}-\mathrm{C}_{25} n$-alkanes, used here as surrogates for all primary S/IVOCs with $C^{*}<3 \mathrm{~g} \mathrm{~m}^{-3}$, have a net diurnal mean mass concentration of $18.7 \mu \mathrm{g} \mathrm{m}^{-3}$ summed over both gas and aerosol phases (Fig. 5). We are aware of only one measurement study of these compounds, that of Fraser et al. (1997) in Los Angeles in 1993. The 24-h mean mixing ratio of decane observed in that study is, coincidentally, exactly equal to that measured during MILAGRO at T0, $445 \mathrm{pptv}$ (Apel et al., 2010). Fraser et al. (1997) measured $16 C_{\geq 11} n$ alkanes totaling $3.1 \mathrm{\mu g} \mathrm{m}^{-3}$ (Fig. 5), and 13 specific branched and/or cyclic $\mathrm{C}_{18-28}$ alkanes totaling $0.24 \mu \mathrm{g} \mathrm{m}^{-3}$. They also observed an unresolved complex mixture (UCM) of branched and cyclic alkanes, whose abundance outweighed that of the $n$-alkanes by over an order of magnitude. Figure 5 shows our simulated concentrations and distributions by carbon number of the larger $n$-alkanes in Mexico City to be comparable to those of the observed sum of $n$-alkanes and

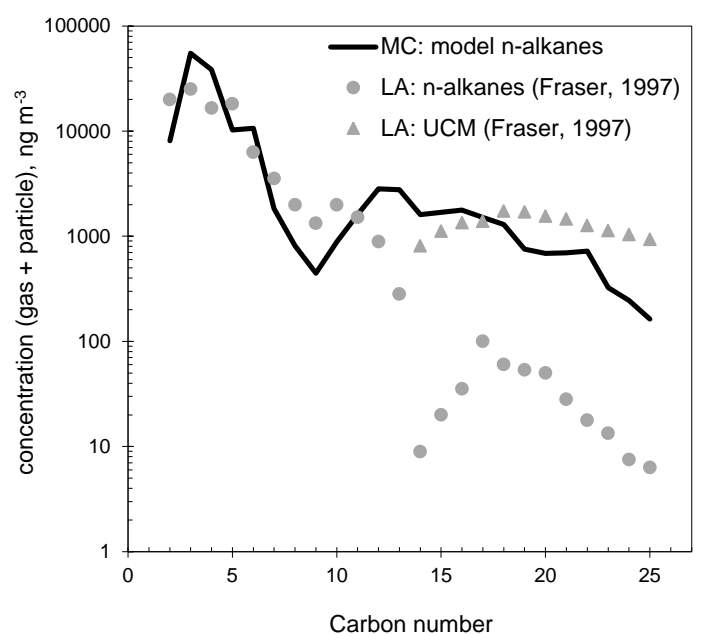

Fig. 5. Diurnal mean concentrations of alkanes in combined gas and aerosol phases. Simulated values are for Mexico City (MC) center. Observations are diurnal means at 4 urban Los Angeles (LA) sites (Fraser et al., 1997). UCM is an observed "unresolved complex mixture" of branched and cyclic alkanes.

UCM in Los Angeles. Together, Figs. 3-5 confirm that our box model is a reasonable representation of the gas phase urban photochemical environment in which the $\mathrm{NO}_{\mathrm{x}}$-catalyzed oxidation of hydrocarbons can lead to SOA evolution.

\subsection{Organic aerosol mass within the city}

The diurnal variations of aerosol mass within Mexico City reflect the combined effects of emissions, photochemistry, temperature, and dilution. Aerosol mass loadings from the Eulerian simulation are shown in Fig. 6. Modeled POA (Fig. 6a) increases during the early morning, as emitted POA accumulates in the shallow night-time boundary layer. Emissions increase sharply after 05:00, producing a peak in POA concentration by about 08:00. Simultaneously, mixed-layer depth and photochemistry also begin to increase, reducing the concentration of POA by mid-morning despite continuing emissions. The SOA mass concentration (Fig. 6b), which remains relatively constant overnight, increases rapidly with the onset of photochemistry, peaking around noon in our simulations. Dilution by ventilation leads to a decline of both POA and SOA mass during the late afternoon and evening. The details of the night-time and early morning profiles, especially with respect to the timing and magnitude of the early morning POA peak, are highly sensitive to assumptions about boundary layer height variation. Our daytime results show generally good agreement with measurements of hydrocarbon-like organic aerosol and oxygenated organic aerosol (HOA and OOA respectively, interpreted as observational surrogates for POA and SOA) at the MILAGRO urban sampling site T0 (Aiken et al., 2009) (Fig. 6). 

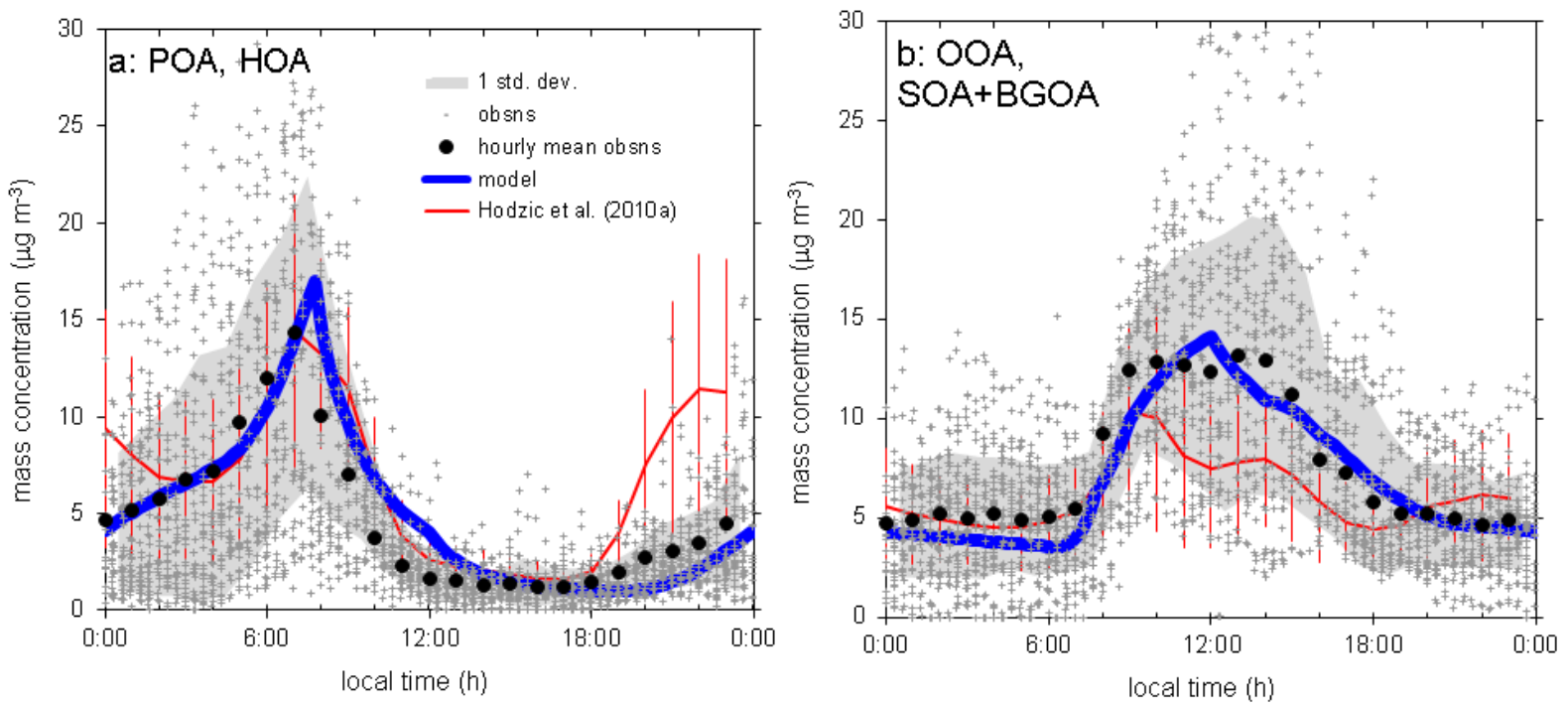

Fig. 6. The diurnal cycle of organic aerosol mass in Mexico City during March 2006. (a) Observed HOA and modeled POA; (b) observed OOA and modeled SOA plus $2 \mu \mathrm{g} \mathrm{m}^{-3}$ background aerosol (BGOA). Observations are from 8-30 March 2006 (Aiken et al., 2009).

Figure 6 shows that simulated POA coincides with the mean of the HOA measurements during the afternoon, at 1 to $2 \mu \mathrm{g} \mathrm{m}^{-3}$. Noontime simulated SOA mass is $12 \mu \mathrm{g} \mathrm{m}^{-3}$ (or $14 \mu \mathrm{g} \mathrm{m}^{-3}$ if the specified background aerosol is also considered), comparable to the mean observed OOA mass of $\sim 13 \mu \mathrm{g} \mathrm{m}^{-3}$ between 11:00 and 15:00 (Aiken et al., 2009). Our results show some similarity to those of Hodzic et al. (2010a) (after the parameterization of Robinson et al., 2007), who used the same quantity of emitted S/IVOC; however, our explicit chemical mechanism shows about $50 \%$ more SOA in the afternoon. The difference is due to differences between the two modeled SOA vapor pressure distributions: the current model calculates vapor pressures for each individual aerosol constituent rather than parameterizing a bulk distribution across a discrete number of bins. It was also noted by Dzepina et al. (2011) that the Robinson et al. (2007) parameterization allows too much evaporation when the aerosol is warmed, as is the case in the afternoon. OA mass development during our Lagrangian simulation, representing conditions in the outflow from the city, will be presented in Sect. 3.4.

\subsection{OA composition and its evolution}

Since our modeled aerosol forms from explicit gas-phase reaction products, we can examine the details of the predicted aerosol composition. Figure 7 shows results from the Eulerian run, illustrating the changing balance within the aerosol between POA (grey areas) and SOA (colored areas) in terms of carbon number of the aerosol constituent. POA dominates the aerosol during the cooler, dark hours of night and early morning, due to condensation of emitted primary species, while SOA dominates during the day and evening in response

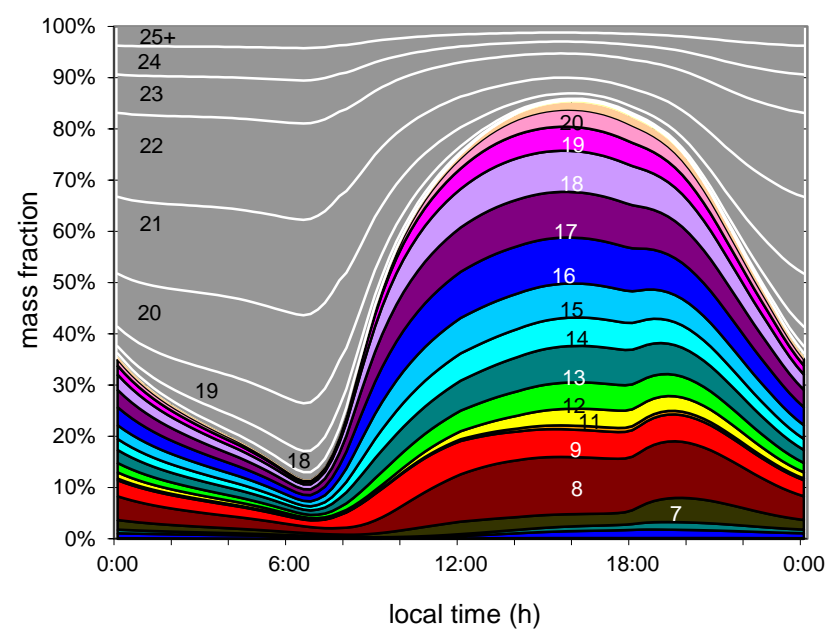

Fig. 7. Composition of simulated organic aerosol within Mexico City. SOA (colors) and POA (grey region) are sorted by carbon number of the individual aerosol constituents.

to photochemical production. Similar diurnal variation in the HOA/OOA balance is observed in Mexico City (Aiken et al., 2009) and elsewhere (e.g. Pittsburgh) (Zhang et al., 2005). The SOA composition is highly diverse with somewhat equal contributions from a range of different carbon numbers, despite the general decline in gas-phase abundance of $n$-alkane precursors with increasing carbon number. This is because the volatility of the precursors and their oxidized products also drops with increasing chain length, consistent with the chamber results of Lim and Ziemann, 2005). For example, the $C^{*}$ values for the $n$-alkane precursors decrease by a factor of 3 to 6 for every additional carbon. Figure 7 shows the resulting POA to be almost exclusively composed of larger 
a) 3pm, at T0

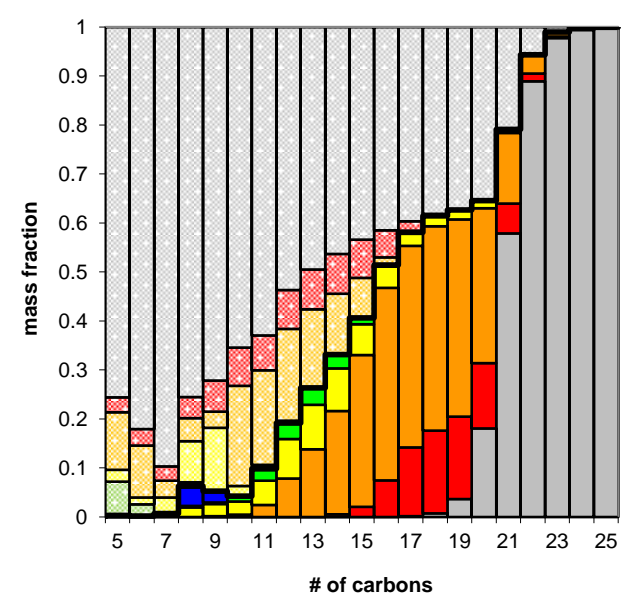

c) $3 \mathrm{pm}, 5$ days downwind

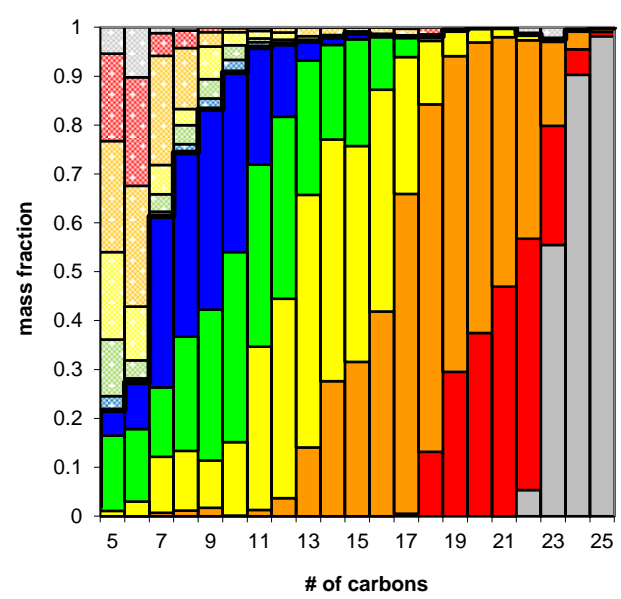

b) 3pm, 2 days downwind

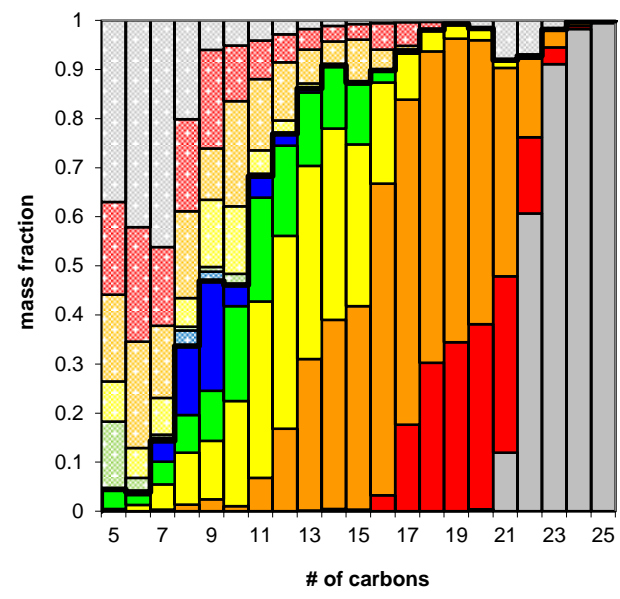

Fig. 8. Gas-particle partitioning by carbon number and number of functional groups. Panels represent the situation at 15:00, (a) at T0, and (b) 2 days and (c) 5 days downwind. Solid colors (lower portion of plots) are particle phase; semi-transparent colors (upper portion of plots) are gas phase. Colors represent number of functional groups per molecule.

SVOC represented by $n$-alkanes with carbon numbers 18 to 25 , with negligible contribution from IVOC (carbon numbers 12 to 16$)$.

Differences in gas-aerosol partitioning between species of different carbon number are further explored in Fig. 8, for the Lagrangian outflow simulation. Figure 8a represents the situation at 15:00 within the city, while Fig. $8 \mathrm{~b}$ and c shows results also at 15:00, but two and five days downwind from the emission sources, respectively. For reference, at the mean incity surface wind speed for March $2006\left(3.4 \mathrm{~m} \mathrm{~s}^{-1}\right)$, two and five days correspond roughly to distances of 300 and $800 \mathrm{~km}$. Primary NMHCs (shown in grey) are found almost exclusively in the gas phase (pale colors) for species with $<19$ carbons, and almost exclusively in the particle phase (bold colors) for $\mathrm{C}_{\geq 22}$. Primary species $\mathrm{C}_{20-22}$ (volatility classes SVOC3 -5 in Table 3 ) show varying degrees of partitioning. Oxidation, shown by the presence of substituent groups and indicated by colors other than grey, reduces volatility and allows $\mathrm{C}_{\leq 20}$ species to partition to the particle phase. NMHCs with $\mathrm{C}_{\geq 16}$ (SVOCs and the least-volatile IVOC class) require only one or two substituent groups (i.e. one generation of oxidation, see following discussion) for rapid condensation, similar to chamber observations (Presto et al., 2009). Incidentally, the lack of significant amounts of highergeneration products for the species with the longest carbon chains supports our computational strategy of limiting mechanism growth to 3 or 5 generations for these species. Smaller species show significant proportions of oxidation products persisting in the gas phase in equilibrium with a more highlysubstituted particle phase.

As the Lagrangian model run progresses (Fig. $8 \mathrm{~b}$ and c) aging increases the degree of oxidation of the VOC mixture, favoring increasing partitioning of species with fewer carbons into the particle phase. The mean molecular weight of 


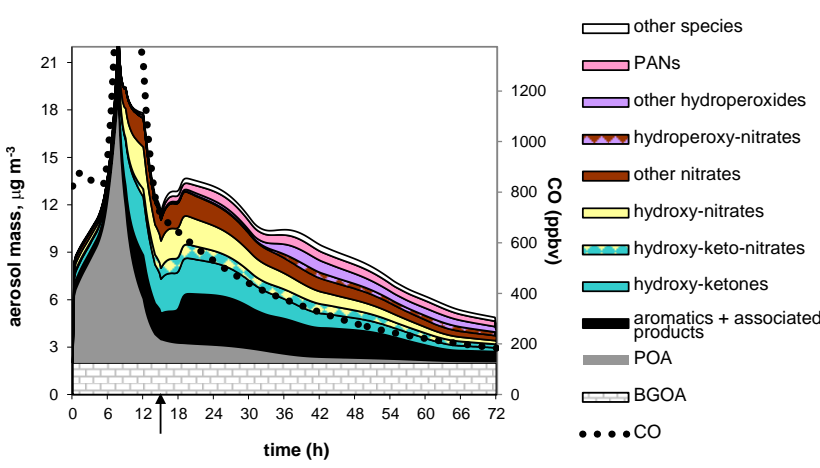

Fig. 9. Evolution of aerosol speciation with time. The arrow shows the time at which Lagrangian conditions begin. The category "aromatics + associated products" includes both substituted aromatics and non-linear products of aromatic oxidation. The scale for gas phase $\mathrm{CO}$ (dotted line) is chosen such that the background value (125 ppbv) coincides on the plot with the level of background aerosol $\left(2 \mu \mathrm{g} \mathrm{m}^{-3}\right)$.

particle phase species decreases as a result (not shown). Dilution also contributes to the evolution of the chemical composition by liberating small amounts of semi-volatile primary $n$-alkanes into the gas phase, as seen for $\mathrm{C}_{20}$ to $\mathrm{C}_{23}$ in Fig. 8 . Their oxidation products repartition to the particle phase, increasing the degree of substitution in the higher molecular weight portion. Both factors combine to reduce the relative importance of primary species with time, consistent with observations (e.g. Zhang et al., 2007; Jimenez et al., 2009).

After 5 days of dilution, our simulated SOA mass concentration is only a fraction (0.15) of our assumed background aerosol, and cannot be considered to represent a discrete plume. In the real world, urban outflow products become progressively mixed with background aerosol components whose compositions reflect a variety of sources and ages (e.g. DeCarlo et al., 2010). Our simulated aerosol development may be viewed as representing continuing oxidation of the dispersed urban outflow portion of the regional background aerosol. The remaining gas phase hydrocarbon mixture contains very little $\mathrm{C}_{>10}$ and is predominantly multi-substituted for $\mathrm{C}_{\geq 5}$, and thus any new particle mass would necessarily consist of highly-substituted low carbon-number species in this chemical scheme.

The chemical composition of the modeled aerosol in the outflow plume is shown in Fig. 9. Initially, the SOA is dominated by hydroxy-ketones, hydroxy-nitrates, higher-carbon species with one nitrate group, and products of the oxidation of aromatic compounds. The di-substituted species generally show $\delta$-spacing of their substituent groups, arising from 1 , 5 hydrogen migration (isomerization) in alkoxy radicals (Orlando et al., 2003) during the first generation of oxidation.

A generic hydrogen migration reaction scheme is outlined in Table 4. OH-initiated hydrocarbon oxidation progresses in the usual way via peroxy (Reaction R1) and (sometimes) alkoxy (Reaction R2a) radical stages to yield mono-functional stable products (Reactions R2b, R3a, R3b, R4). Alternatively, for alkoxy radicals with at least 4 carbons and little steric hindrance, an isomerization is possible (Reaction R5). This involves the formation of a 6-membered ring intermediate, leading to transfer of a hydrogen atom to the alkoxy radical group from a carbon in the $\delta$-position (that is, four carbons away from the $\mathrm{O}$. radical). The resulting $\delta$-hydroxy alkyl radical converts rapidly to a $\delta$-hydroxy peroxy radical (Reaction R6), followed by formation of a nitrate (Reaction R7b), ketone (Reactions R7a, 8), or peroxide (Reaction R9) group to yield a di-substituted first-generation reaction product. Lim and Ziemann (2009) observed disubstituted hydroxycarbonyls to undergo heterogeneous reactions, leading to products with greater volatility. However these reactions mainly occur under dry conditions and are not considered in our gas-phase model.

At dusk on the first day of simulation, there is a sudden increase in aerosol mass. The $\mathrm{RO}_{2}$ radicals produced in the early evening via gas phase $\mathrm{NO}_{3}$ chemistry quickly react to form less-volatile products, some of which condense. By far the strongest contribution to the mass increase comes from aromatic species, mainly dinitro-phenols and hydro-peroxynitro-arenes (Bloss et al., 2005b). As the Lagrangian plume ages, its chemical diversity further increases. During the second day of simulation peroxy radical reactions shift from being dominated by $\mathrm{NO}$ to $\mathrm{HO}_{2}$, producing an increase in the hydro-peroxide fraction of the predicted aerosol composition. Peroxy-acyl-nitrates (PANs) also increase in relative importance with time, because of the gas phase fragmentation of long-chain hydrocarbons and subsequent oxidation of the fragment aldehydes:

$$
\begin{aligned}
& \mathrm{R}-\mathrm{CH}(\mathrm{O})+\mathrm{OH}\left(+\mathrm{O}_{2}\right) \rightarrow \mathrm{H}_{2} \mathrm{O}+\mathrm{R}-\mathrm{C}(\mathrm{O})(\mathrm{OO} .) \\
& \mathrm{R}-\mathrm{C}(\mathrm{O})(\mathrm{OO} .)+\mathrm{NO}_{2} \rightarrow \mathrm{R}-\mathrm{C}(\mathrm{O})\left(\mathrm{OONO}_{2}\right)
\end{aligned}
$$

The evolution of the chemical composition may be summarized by correlating ratios of major elemental constituents on a Van Krevelen diagram. Heald et al. (2010) used such a diagram to summarize observations from a wide range of locations, and found that ratios of oxygen to carbon $(\mathrm{O} / \mathrm{C})$ and hydrogen to carbon $(\mathrm{H} / \mathrm{C})$ cluster close to an empirical line with slope -1 and origin $\mathrm{H} / \mathrm{C}=2$. The development of elemental ratios in the total organic aerosol ( $\sum \mathrm{OA}$, the sum of POA, SOA, and BGOA, background organic aerosol) in our Lagrangian simulation is similar to the range of observations (Fig. 10). The y-intercept of the line is defined by POA, composed in the model of $\mathrm{C}_{18-25} n$-alkanes and yielding $\mathrm{H} / \mathrm{C} \approx 2.1$. $\mathrm{O} / \mathrm{C}$ rises and $\mathrm{H} / \mathrm{C}$ drops with increasing aerosol age, leading to an anti-correlation between $\mathrm{O} / \mathrm{C}$ and $\mathrm{H} / \mathrm{C}$. During the first 3 days of outflow, while modeled $\sum \mathrm{OA}$ composition is dominated by POA and SOA rather than by BGOA, its slope on the Van Krevelen diagram is close to -1 . Modeled SOA (not plotted explicitly) shows a slope of -1 on the first day, meaning that oxygen replaces hydrogen 
Table 4. Example hydrogen migration reaction sequence, including names of organic products.

\begin{tabular}{|c|c|c|c|c|}
\hline \multirow{3}{*}{$\begin{array}{l}\mathrm{R}-\left(\mathrm{CH}_{2}\right)_{4}-\mathrm{R}^{\prime}+\mathrm{OH}\left(+\mathrm{O}_{2}\right) \\
\mathrm{R}-\mathrm{CH}(\mathrm{OO} \cdot)-\left(\mathrm{CH}_{2}\right)_{3}-\mathrm{R}^{\prime}+\mathrm{NO}\end{array}$} & $\rightarrow$ & $\mathrm{H}_{2} \mathrm{O}+\mathrm{R}-\mathrm{CH}(\mathrm{OO})-.\left(\mathrm{CH}_{2}\right)_{3}-\mathrm{R}^{\prime}$ & peroxy radical & (R1) \\
\hline & & D.) $-\left(\mathrm{CH}_{2}\right)_{3}-\mathrm{R}^{\prime}$ & & (R2a) \\
\hline & $\rightarrow$ & $\mathrm{R}-\mathrm{CH}($ & onal nitrate & $\mathrm{R} 2 \mathrm{~b})$ \\
\hline \multirow[t]{2}{*}{$\mathrm{R}-\mathrm{CH}(\mathrm{O})-.\left(\mathrm{CH}_{2}\right)_{3}-\mathrm{R}^{\prime}+\mathrm{O}_{2}$} & $\rightarrow$ & $-R^{\prime}$ & ono-functional ketone & R3a) \\
\hline & $\rightarrow$ & $\left.\mathrm{CH}_{2}\right)_{2}-\mathrm{R}^{\prime}$ & & 23b) \\
\hline $\mathrm{R}-\mathrm{CH}(\mathrm{OO})-.\left(\mathrm{CH}_{2}\right)_{3}-\mathrm{R}^{\prime}+\mathrm{HO}_{2}$ & $\rightarrow$ & & & 4) \\
\hline & $\rightarrow$ & & & R5) \\
\hline $\mathrm{R}-\mathrm{CH}(\mathrm{OH})-\left(\mathrm{CH}_{2}\right)_{2}-\mathrm{CH}()-.\mathrm{R}^{\prime}+\mathrm{O}_{2}$ & $\rightarrow$ & $\mathrm{R}-\mathrm{CH}(\mathrm{OH})-\left(\mathrm{CH}_{2}\right)_{2}-\mathrm{CH}(\mathrm{OO})-.\mathrm{R}^{\prime}$ & lical & (R6) \\
\hline \multirow[t]{2}{*}{$\mathrm{R}-\mathrm{CH}(\mathrm{OH})-\left(\mathrm{CH}_{2}\right)_{2}-\mathrm{CH}(\mathrm{OO})-.\mathrm{R}^{\prime}+\mathrm{NO}$} & $\rightarrow$ & $\begin{array}{l}\mathrm{NO}_{2}+\mathrm{R}-\mathrm{CH}(\mathrm{OH})-\left(\mathrm{CH}_{2}\right)_{2}-\mathrm{CH}(\mathrm{O} .)-\mathrm{R}^{\prime} \\
\mathrm{R}-\mathrm{CH}(\mathrm{OH})-(\mathrm{CH})_{2}-\mathrm{CH}(\mathrm{ONO})-\mathrm{R}^{\prime}\end{array}$ & $\delta$-hydroxy alkoxy radical & (R7a) \\
\hline & $\rightarrow$ & $\begin{array}{l}\mathrm{R}-\mathrm{CH}(\mathrm{OH})-\left(\mathrm{CH}_{2}\right)_{2}-\mathrm{CH}\left(\mathrm{ONO}_{2}\right)-\mathrm{R}^{\prime} \\
\mathrm{HO}_{2}+\mathrm{R}-\mathrm{C}(\mathrm{O})-\left(\mathrm{CH}_{2}\right)_{2}-\mathrm{CH}(\mathrm{OH})-\mathrm{R}^{\prime}\end{array}$ & & $\begin{array}{l}\text { (R7b) } \\
\text { (R8) }\end{array}$ \\
\hline $\mathrm{R}-\mathrm{CH}(\mathrm{OH})-\left(\mathrm{CH}_{2}\right)_{2}-\mathrm{CH}(\mathrm{OO} \cdot)-\mathrm{R}^{\prime}+\mathrm{HO}_{2}$ & $\rightarrow$ & $\mathrm{O}_{2}+\mathrm{R}-\mathrm{CH}(\mathrm{OH})-\left(\mathrm{CH}_{2}\right)_{2}-\mathrm{CH}(\mathrm{OOH})-\mathrm{R}^{\prime}$ & $\delta$-hydroxy peroxide & (R9) \\
\hline
\end{tabular}

on an atom-for-atom basis during early oxidation. It is interesting to note that the 1,5 isomerization reaction described in Table 4 leads to a net loss of two hydrogen atoms and a gain of two oxygen atoms, consistent with this slope. The 6 -day mean SOA gradient is -0.6 , or 5 oxygen atoms per 3 hydrogen atoms. $\sum \mathrm{OA}$ composition is influenced by the assumed composition of BGOA, and increasingly so as dilution and mixing progress. Adopting mean surface regional BGOA values of $\mathrm{O} / \mathrm{C}=0.68$ and $\mathrm{H} / \mathrm{C}=1.25$ (Jimenez et al., 2009) progressively steepens the plotted slope (colored lines in Fig. 10). Assuming background $\mathrm{O} / \mathrm{C}$ and $\mathrm{H} / \mathrm{C}$ ratios of $\sim 1$ and $\sim 1.1$, similar to aircraft observations during MILAGRO (Heald et al., 2010; after Aiken et al., 2008), produces a shallower slope (grey line in Fig. 10) especially during the later portion of the simulation.

The agreement between our modeled elemental ratios and observations within Mexico City during MILAGRO (points in Fig. 10) (Aiken et al., 2008) is also good, within the range of scatter expected in such plots (see Heald et al., 2010). However, our nitrogen-to-carbon ratios (not shown) fall between 0.075 and 0.09 , significantly exceeding observations (e.g. $\leq 0.01$ in the Mexico City area; Aiken et al., 2008), likely as a symptom of the systematic under-representation in aerosol mass-spectrometer (AMS) observations of organonitrates (Bruns et al., 2010; Farmer et al., 2010). The dotted line in Fig. 10 shows the model O/C ratio recalculated to take this into account by omitting two oxygens from each modeled nitrate group. The recalculation further improves the agreement between model and observations.

One significant point of disagreement between the model and measurements concerns the timescale of evolution of the elemental ratios, that is, the rate at which the aerosol moves down and to the right on the Van Krevelen plot. Results from the Eulerian phase (the first day) of simulation show smaller $\mathrm{O} / \mathrm{C}$ and larger $\mathrm{H} / \mathrm{C}$ than measured within Mexico City. Our $\sum \mathrm{OA}$ ratios encompass the measured range only after one to two additional days of Lagrangian simulation. Thus, the oxidative development of our simulated aerosol is significantly slower than suggested by the observations.
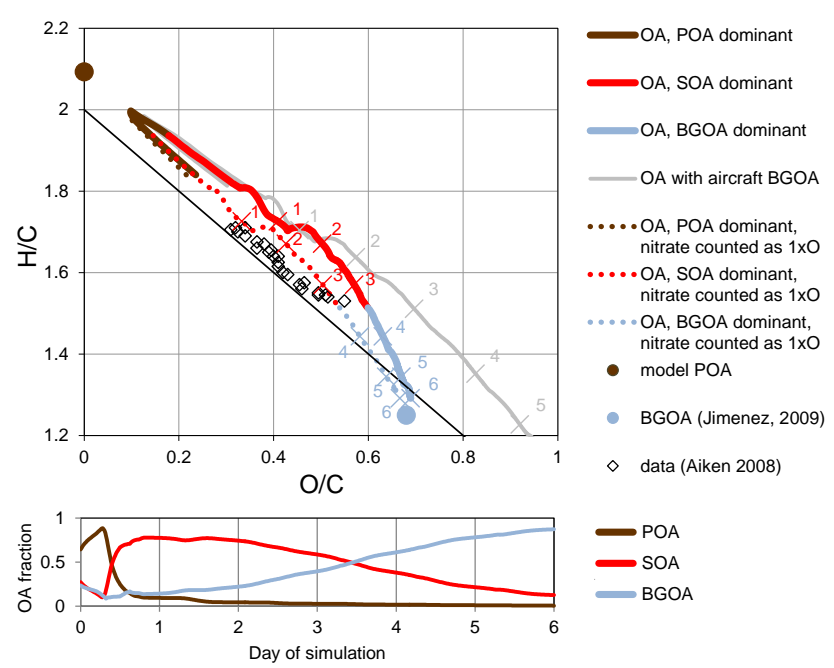

Fig. 10. Van Krevelen diagram showing the evolution of elemental ratios in modeled $\sum$ OA during both Eulerian (before 15:00 on day 1) and Lagrangian phases of the simulation. BGOA composition is defined as the mean of regional surface observations (Jimenez et al., 2009), except for the grey line which defines BGOA as the mean of airborne observations (Heald et al., 2010; after Aiken et al., 2008). The dotted line shows OA evolution if ratios count only one $\mathrm{O}$ atom per $\mathrm{ONO}_{2}$ group. Midnight values for each of the 6 days of simulation are indicated by numbered diagonal ticks. Observations are hourly means of measurements at T0 (Aiken et al., 2008). The -1 slope is included for illustrative purposes. The lower panel shows the development of fractional mass contributions of the different $\mathrm{OA}$ types to $\sum \mathrm{OA}$.

\subsection{OA production in urban outflow}

In the Lagrangian simulation, the air parcel detaches from the surface at 15:00 on the first day, whereupon emissions cease and a constant dilution rate is established. The rate of change of SOA concentration may be expressed in terms of the local instantaneous rate of SOA net production via condensation and evaporation, $p$, and the loss to dilution: 
$\frac{d[\mathrm{SOA}]}{d t}=p(t)-k_{\mathrm{dil}[\mathrm{SOA}]}$

Figure 11a shows the development of [SOA] and $p$ for 3.5 days of the Lagrangian simulation. Despite ongoing dilution, [SOA] continues to grow to a maximum of $11.1 \mathrm{\mu g} \mathrm{m}^{-3}$ at 19:00 on the first evening (see Fig. 11b), owing to continuing chemical production both before and just after nightfall. Thereafter [SOA] decreases as the plume expands downwind of the city, but $p$ remains positive in the outflow for most of the simulation (i.e. aerosol growth outweighs evaporative loss).

While $p$ represents local SOA production, the SOA generated in urban outflow occupies an increasingly wide region as the plume disperses. The aggregated regional influence may be assessed by adjusting $p$ for dilution, in effect considering the growth of particles along all trajectories dispersing from one initial air parcel. The relationship between initial air parcel volume $V_{0}$ and the virtual volume $V_{t}$ into which the SOA from that air parcel may be considered to have dispersed at time $t$ is expressed as:

$V_{t} / V_{0}=e^{t k_{\mathrm{dil}}}$

We define $M_{t}$ as the SOA mass at time $t$ in a dispersed air parcel with original volume $V_{0}$ of $1 \mathrm{~m}^{3}$ :

$M_{t}=V_{t}[\mathrm{SOA}]_{t}=e^{t k_{\mathrm{dil}}}[\mathrm{SOA}] t$

A time-dependent mass production rate $M^{\prime}$ may then be found, with units of mass per day per original cubic metre, $\mu \mathrm{g} \mathrm{d}^{-1} \mathrm{~m}_{0}^{-3}$ :

$M^{\prime}(t)=\frac{d M}{d t}=e^{t k_{\mathrm{dil}}}\left(\frac{d[\mathrm{SOA}]}{d t}+d_{\mathrm{dil}}[\mathrm{SOA}]_{t}\right)$

The strongest mass production rates, $M^{\prime}>40 \mu \mathrm{g} \mathrm{d}^{-1} \mathrm{~m}_{0}^{-3}$, are seen during the first afternoon, as strong photochemical production occurs due to the oxidation of freshly emitted precursors (Fig. 11a). This production rapidly slows towards sunset. At dusk, $\mathrm{NO}_{3}$-mediated chemistry produces another strong spike in SOA production, with mass production rates of $\sim 30 \mu \mathrm{g} \mathrm{d}^{-1} \mathrm{~m}_{0}^{-3}$ from this process alone. Photochemical aerosol production continues to dominate over evaporation during the first two days of outflow, while cooler temperatures at night lead to additional aerosol formation via condensation. Net losses occur only around dawn as air temperature begins to rise, causing re-evaporation. The model maintains the same diurnal temperature cycle throughout the simulation, for simplicity. If instead the air parcel were cooled to represent lofting into the free troposphere, condensation and therefore SOA mass would both increase relative to the calculations presented here.

The dispersed particulate mass $M$ reaches $31 \mu \mathrm{g} \mathrm{m}_{0}^{-3}$ on the third morning of outflow (around 78h, Fig. 11b). After this point, daytime aerosol loss occurs when dilution-induced
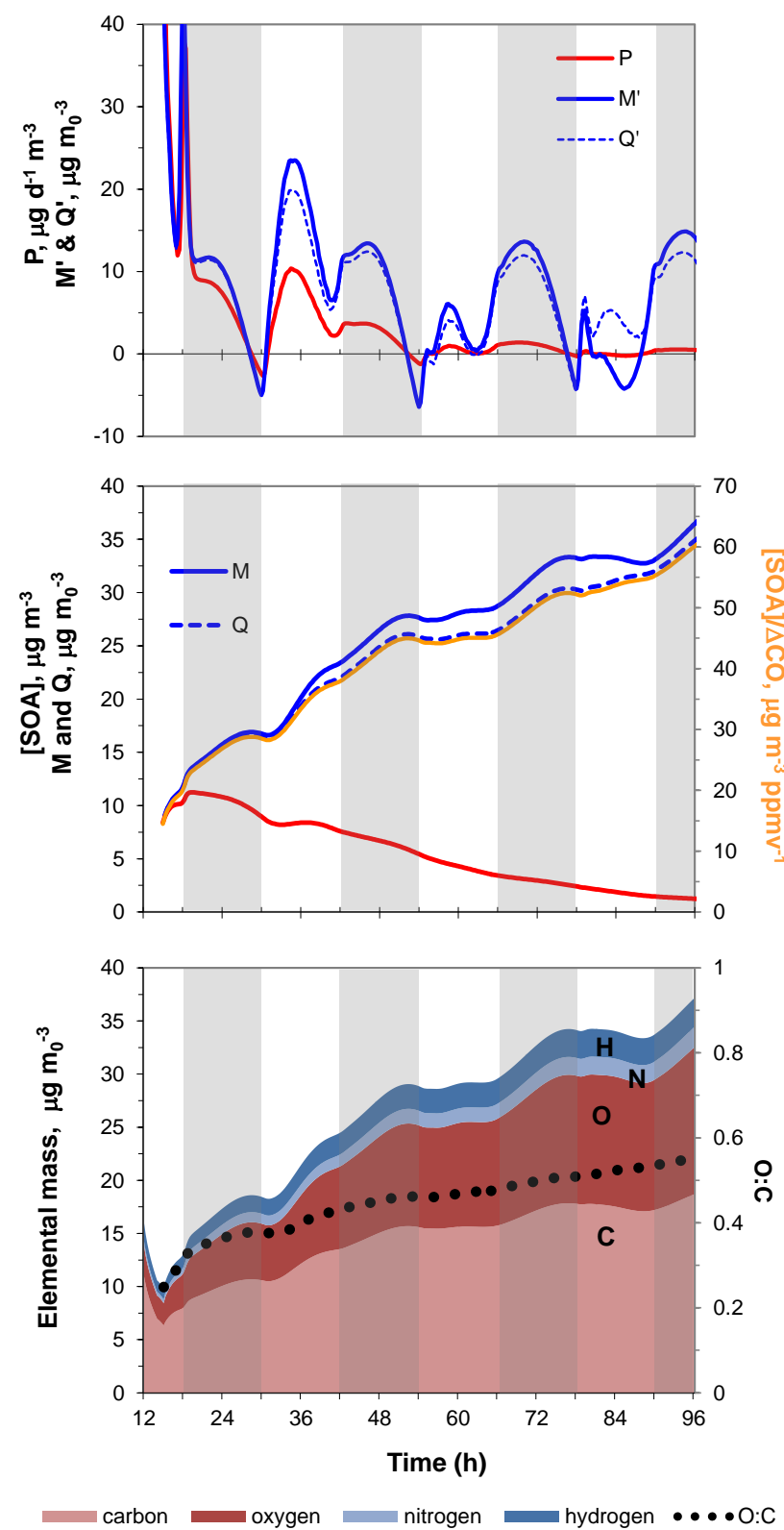

Fig. 11. Aerosol production during the Lagrangian run. (a) SOA production rates. (b) SOA concentration and mass in the dispersing air parcel. (c) Elemental composition of dispersing aerosol mass $M$. Grey shaded regions indicate approximate hours of darkness.

evaporation dominates $M^{\prime}$, and as the gas-phase burden of potential aerosol precursors declines. Diurnally-averaged production remains positive however, since night-time condensation remains strong, so that $M$ continues to increase on the fourth outflow night and beyond. An elemental analysis (Fig. 11c) shows that carbon is added to the aerosol continuously between hours 15 and 48, indicating ongoing formation of new SOA. Later in the simulation, carbon addition slows, continuing at night but being partially offset 
by evaporation during the day. Aerosol oxygen increases almost continuously throughout the run, likely due to a combination of gas-phase processing of evaporating aerosol constituents which then recondense, and first-time condensation of smaller gas-phase species with larger oxygen to carbon ratios. Thus the $\mathrm{O} / \mathrm{C}$ ratio of the model-generated aerosol (excluding the background component) generally increases throughout, reaching $\sim 0.55$ after three days of outflow.

Figure 11 also presents $Q$, which is an approximation of the dispersed SOA mass $M$, calculated using the observable quantity $\triangle \mathrm{CO}$ (see Appendix). $\triangle \mathrm{CO}$ is defined as the local enhancement of [CO] above its background value, and is used as a tracer of the dispersal of urban emissions. The slight differences between $M$ and $Q$ (Fig. 11) result from the finite chemical lifetime of $\mathrm{CO}$. The Appendix to this paper discusses $Q$ and $[\mathrm{SOA}] / \triangle \mathrm{CO}$ in more detail, demonstrating that the use of $\Delta \mathrm{CO}$ as a tracer is a reasonable approximation.

\section{Discussion}

Use of an explicit gas-phase mechanism in a simple box model allows us to investigate details of organic aerosol formation and composition that are not available by other means. In this section we discuss our findings for this urban case study, in the context of current understanding of aerosol development in urban outflow. We distinguish between robust results, which we have found to be intrinsic features of results from this model, and suggestions arising from our results, which are interesting but are more initialisationdependent.

\subsection{Aerosol growth continues in outflow}

Our first robust result is that photochemical production and condensation of SOA species outweigh dilution-induced evaporation from particles in the outflow plume for several days downwind of the source, leading to net positive SOA production rates for most of the simulation period. Although OA concentrations decrease with time in the outflow plume, we predict continuing net production that increases plumeintegrated OA mass for at least 3 days downwind. OA mass grows by a factor of $>3$ on that timescale in the present study. Numerically similar results were obtained by Dzepina et al. (2011) in a box model sensitivity study using the VBS approach. The impacts of SOA on the integrated regional scale, which is the scale relevant for climate, are thus likely to be much greater than concentrations in the source region imply.

One point of uncertainty relevant to our prediction of continuing aerosol growth is the difference in aging timescales between our model results and field observations. Both our model-derived aerosol elemental ratios and $[\mathrm{SOA}] / \Delta \mathrm{CO}$ values (see Appendix) compare well with observed values but develop more slowly. Our model aerosol chemical evolution timescale is roughly twice that suggested by observations. Other potentially important processes will be discussed later.

Recent observational studies indicate that SOA forms rapidly from urban emissions, with significant mass increase occurring within a few hours (Volkamer et al., 2006; DeCarlo et al., 2008). Opinions are divided on whether new OA mass continues to be formed at longer timescales. Dunlea et al. (2009) concluded that SOA forms during the first day in free-troposphere Asian outflow, and then evolves chemically for at least a week without significant new mass formation. Morgan et al. (2010) see little change in OA mass concentrations far downwind in continental European outflow, which suggests either that continued formation outweighs the effects of dilution with background air, or possibly that regional background OA concentrations are already comparatively high owing to the multiple sources in this region. In the Mexico City case, Kleinman et al. (2008) propose new OA formation in urban outflow air for up to 1 day, based on increasing OA/ $\Delta$ CO. DeCarlo et al. (2008), however, suggest a loss of OA carbon outside the city, based on a flat or declining regional relationship between $\mathrm{OA} / \Delta \mathrm{CO}$ and distance from Mexico City. This conclusion is dependent on whether it is possible, in observations that do not specifically target an outflow plume, to separate recently-formed SOA from the regional background aerosol with which it is being progressively mixed, and which likely contains outflow-origin SOA with a mixture of ages (Emmons et al., 2010).

We recognize that observation of continuing growth of SOA in urban outflow becomes extremely challenging as it disperses and mixes with the aged regional background aerosol. Nevertheless, and consistent with the reasoning of Kroll and Seinfeld (2008) and with the model results of Hodzic et al. (2010a) and Dzepina et al. (2011), our model results strongly suggest that, as long as gas-phase precursors are available, new production of OA is most likely still occurring on the regional scale in addition to the expected continuing oxidative aging. We suggest that the contribution of this continuing production to regional aerosol burdens may be significant.

\subsection{The aerosol is chemically diverse}

The second robust result is that simulated OA contains a multitude of condensed species and is highly diverse in terms of molecular size and functionality. No single chemical species dominates either the primary or secondary OA fraction. We restricted the size of our available pool of aerosol precursors by using $n$-alkanes as surrogates for all emitted organic precursor molecules of similar volatility, by lumping together chemically similar isomers, and by omitting biogenic compounds. Without these simplifications, the simulated aerosol would contain an even greater number of individual chemical species. The 100 most abundant OA species contribute only about $40 \%$ to $50 \%$ of the calculated OA mass during 
the second day of simulation. To reach $70 \%$ of the mass requires over 1000 species. This level of complexity is realistic: one urban study using highly specific measurement techniques identified over 300 named organic aerosol constituents including branched and $n$-alkanes and some of their reaction products (Williams et al., 2010), and another study found evidence of more than 10000 separate species in organic aerosol (Hamilton et al., 2004).

Furthermore, and also as a robust result, the chemical diversity of the simulated particle phase increases with time. During the first afternoon, the particle phase in the urban source region contains rapidly-condensed species with a relatively even distribution of carbon numbers, whether as pure long-chain $n$-alkanes, or as low volatility, high carbon number first-generation reaction products. This early-origin particulate material ages over several days in the outflow plume as it slowly evaporates, oxidizes, and re-condenses. The substantial quantity of gas-phase organic material in the plume is also subject to continuing oxidation chemistry, and either fragments, yielding smaller products and $\mathrm{CO}$ or $\mathrm{CO}_{2}$, or becomes progressively more functionalized and less volatile. Even precursors with relatively few carbons (down to $\mathrm{C}_{5}$ ) can lead to condensable multi-generation oxidation products over a timescale of several days (e.g. Kroll et al., 2011). The particle phase thus progressively acquires a large number of newly formed low-carbon, high-oxidation constituents, which contribute to particle mass formation and chemical complexity.

\subsection{Specific chemical identity of aerosol constituents}

The simulated particle phase contains significant contributions from organic nitrates ( $\sim 50 \%$ by mass), and from $\delta$ difunctional species formed in the first generation of oxidation ( $\sim 30 \%$ by mass). Similar products have been identified in the laboratory under high $\mathrm{NO}_{\mathrm{x}}$ conditions (Lim and Ziemann, 2005; Presto et al., 2010), and also in polluted urban conditions. Russell et al. (2011) observed negligible organonitrates in a wide range of aerosol samples including from Mexico City, and attributed their absence to inaerosol hydrolysis in humid conditions. However, organonitrates observed in urban Southern California during lesshumid periods could contribute up to $24 \%$ of OA mass (Day et al., 2010; D. Day, personal communication, 2011), and Oezel et al. (2010) identified several secondary organic nitro compounds in OA in Birmingham, UK. Our results suggest that, at least under relatively dry conditions, organonitrates formed in the gas phase are likely to contribute significantly to SOA mass.

The chemical identity of the simulated SOA shifts in response to the ambient chemical environment. As the outflow simulation progresses and urban-origin plume $\mathrm{NO}_{\mathrm{x}}$ decreases, contributions from hydro-peroxides and PANs increase in relative importance. Several chamber studies (e.g. $\mathrm{Ng}$ et al., 2007, and references therein) have shown aerosol yield increasing at low $\mathrm{NO}_{\mathrm{x}}$, indicating that organic hydroperoxides contribute to SOA formation. More specifically, Rickard et al. (2010) observed evidence in low- $\mathrm{NO}_{\mathrm{x}}$ experiments of high molecular weight hydroperoxide products, whose low vapor pressures suggest they would contribute to SOA growth. Our results are consistent with these experimental data, and suggest that OA formation should continue even in relatively unpolluted air.

It is noteworthy that our simulations produce only small amounts of carboxylic acids in the gas phase (mostly from the ozonolysis of unsaturated hydrocarbons) while observations show that many organic acids are commonly abundant in particles. We previously showed that another more limited explicit gas phase mechanism could not generate the observed organic acid concentrations, and suggested that inparticle oxidation is at play (Aumont et al., 2000). The more explicit chemical mechanism used here reaffirms the earlier results, at least for the Mexico City mix that is heavily influenced by alkanes and aromatics.

\subsection{Simulated SOA mass}

The GECKO-A model of explicit gas-phase chemistry is capable of generating quantities of SOA comparable to those observed in Mexico City (Aiken et al., 2009). Other recent model studies (Dzepina et al., 2009; Tsimpidi et al., 2010; Hodzic et al., 2010a) have produced realistic quantities of SOA by first increasing the mass of the particulate emissions inventory to account for assumed gas phase equilibrium coemissions, and then applying parameterized volatility reductions to represent the effects of gas-phase chemistry. Our results build on the successes of those studies by using similar estimates of semi- and intermediate volatility precursor emissions, but specifying their identity as $n$-alkanes and applying detailed and realistic gas phase chemistry. This produces close agreement with observations almost throughout the diurnal cycle (Fig. 6). The estimated SVOC and IVOC precursors and their reaction products contribute about $70 \%$ of the resulting modeled SOA, with the remaining $30 \%$ originating mostly from single-ring aromatic precursors.

The SOA mass agreement we find is, however, more fortuitous than realistic. Since our model explicit chemistry is restricted to the gas phase, we necessarily omit several complex but potentially important classes of reactions. Processes that would likely increase SOA mass formation include aqueous or multiphase chemistry (e.g. Blando and Turpin, 2000; Aumont et al., 2000; Clegg et al., 2001; Gelencsér and Varga, 2005; Ervens and Volkamer, 2010), heterogeneous reactions (George and Abbatt, 2010), and accretion reactions (Barsanti and Pankow, 2004; Pun and Seigneur, 2007). Processes which potentially decrease SOA mass include particle-phase fragmentation (Kroll et al., 2009), and particle-phase isomerization and dehydration reactions (Lim and Ziemann, 2005; Lim and Ziemann, 2009), although in the latter case, 
subsequent gas phase chemistry could yield smaller SOA molecules.

We also omit emissions and chemistry of some potential SOA precursors. Naphthalene and other polycyclic aromatic hydrocarbons (PAHs) have been suggested as significant precursors to SOA (e.g. Chan et al., 2009; Shakya and Griffin, 2010). Gaseous naphthalene contributes $>84 \%$ of the total gas-plus-particle PAH mass in Mexico City (Mugica et al., 2010) and reported concentrations in the city center vary between a mean of $0.05 \mu \mathrm{g} \mathrm{m}^{-3}$ (Guzman-Torres et al., 2009) and spikes of up to $1 \mathrm{ppbv}$ (equal to $\sim 4 \mu \mathrm{g} \mathrm{m}^{-3}$ ) (Jobson et al., 2010). For comparison, single-ring aromatic precursors account for up to $7.4 \mu \mathrm{g} \mathrm{m}^{-3}$ of our simulated SOA $(\sim 30 \%$ of SOA mass), significantly outweighing the potential PAH contribution. Elemental ratio analysis also argues against a dominant PAH contribution to SOA. Addition of naphthalene (with $\mathrm{H} / \mathrm{C}=0.8$ ) to the POA+SOA mixture in Fig. 10 flattens the gradient and lowers the intercept of the $\sum \mathrm{OA}$ elemental ratio relationship. The naphthalene measurements and elemental ratio considerations both suggest that PAHs cannot make more than about a $10 \%$ contribution to SOA.

Biogenic precursors were omitted for simplicity in this urban case study; however, a recent study of the relative abundances of fossil and modern carbon in OA in Mexico City suggests significant contributions from regional biogenic, biomass burning, and non-fossil sources (Hodzic et al., 2010b), all of which would lead to higher OA loadings than simulated here.

Another factor affecting simulated SOA mass is the choice of boiling point and vapor pressure estimation methods. The boiling point $\left(T_{\mathrm{b}}\right)$ scheme of Joback and Reid (1987) leads to the highest simulated OA masses among the three methods reviewed by Barley and McFiggans (2010). The vapor pressure equation of Myrdal and Yalkowsky (1997), when combined with the $T_{\mathrm{b}}$ scheme of Joback and Reid (1987) as in the current study, systematically overestimates chamber results for SOA production from $\alpha$-pinene, by factors of two or more (Valorso et al., 2011). These biases likely lead the model to be too efficient at producing SOA, compensating for the shortfall in modeled SOA mass that might be expected from the omissions in reactions and precursors noted above. A good agreement despite ignoring several precursors and suspected or known SOA formation pathways suggests that either GECKO-A is too efficient at producing SOA, that the emissions of the unmeasured S/IVOCs were overestimated, or that both sources and sinks were underestimated.

Dry deposition can potentially reduce regional SOA loadings. We have performed a sensitivity calculation with a 3-D regional model (CHIMERE, as in Hodzic et al., 2010, which parameterized dry deposition at velocities similar to $\mathrm{HNO}_{3}$ to get an upper estimate of its effect. The results (not presented in detail here) show maximum reductions in anthropogenic SOA within Mexico City on the order of 5 to $25 \%$ when compared to a non-deposition simulation. In the outflow simulation case, air parcel lofting further reduces the potential for dry deposition. Washout during rain events is, of course, a major sink for atmospheric aerosols but is not included in the dry-conditions simulation presented here.

\section{Conclusions}

The model reproduces well the observed diurnal variation of organic particle mass concentrations in Mexico City, with POA peaking in the early morning at $15-20 \mu \mathrm{g} \mathrm{m}^{-3}$, and SOA peaking at $10-15 \mu \mathrm{g} \mathrm{m}^{-3}$ during mid-day (Fig. 6). The excellent agreement in peak concentrations may be somewhat fortuitous as discussed, but the agreement on temporal shapes is strong evidence of photochemistry both consuming POA and generating SOA. In the model, the SOA is generated mainly from the estimated semi-volatile surrogate species (alkanes), and to a lesser extent from the lighter aromatics. Resulting OA H/C ratios are 1.5-2.0, in fairly good agreement with observations (Fig. 10). We note that other proposed precursors such as naphthalene (Chan et al., 2009) or glyoxal (Ervens and Volkamer, 2010) would yield much lower $\mathrm{H} / \mathrm{C}$ values. If alkanes, whether linear or branched, are indeed major SOA precursors, our model predicts that $\delta$-hydroxy ketones and nitrates should be persistent chemical constituents of the particle phase. The $\mathrm{O} / \mathrm{C}$ ratios are also in reasonable agreement with observations, although in our model the higher $\mathrm{O} / \mathrm{C}$ ratios are achieved only after several days of photochemical processing in the outflow plume, while observations suggest that such high $\mathrm{O} / \mathrm{C}$ ratios may already arise in the city. The N/C ratios predicted by the model are much higher than observed, but it is unclear if this is due to nitrate elimination from particles, or instrumental difficulties in observing the N/C ratio (Farmer et al., 2010; Bruns et al., 2010).

From a global or regional perspective, perhaps the most intriguing modeling result is that the plume-integrated mass of the particles continues to grow for several days downwind of the urban source region. In the absence of chemical processing, dilution of the urban plume by cleaner background air would lead to evaporation of the particles (or at most to constant particle mass if vapor pressures approach zero), because particle/gas partitioning is proportional to the mass concentration of particles (Pankow, 1994b; Odum et al., 1996). Quite contrarily, our model predicts continuing particle growth even after dilution (Fig. 11). The growth occurs because of continuing gas phase reactions of the hydrocarbon precursors and their partly oxidized intermediates, yielding molecules of progressively lower vapor pressures. This may be characteristic of $n$-alkane chemistry as currently implemented in the GECKO-A model, based on structure-activity relations generalized from laboratory studies on smaller alkanes (Aumont et al., 2005). A more rapid evolution could be achieved by changing key structure-activity relations, e.g. by changing the rate of alkoxy radical fragmentation relative to isomerization, but at present there are no laboratory data to 
justify such changes to the model. Additional growth would be expected if the air parcel experiences colder temperatures, such as during lofting of boundary layer air, but as this is not considered in our model, the growth in Fig. 11 is due to chemical production of lower vapor pressure compounds, rather than cooling. Aircraft-based measurements do not support ongoing growth of the $\Delta \mathrm{OA} / \Delta \mathrm{CO}$ ratio (DeCarlo et al., 2008), but the measurement of this ratio becomes progressively less certain downwind as both numerator and denominator approach the background fluctuations. Thus, the question remains open about the potential multi-day growth of SOA, which if confirmed by observations would have important implications for the nature of the regional background aerosol and its impact on radiative budgets (e.g. Fast et al., 2009).

The chemical detail presented here is obviously not intended for direct use in three-dimensional chemistrytransport models. Rather, we used this model (i) to show that explicit gas phase chemistry can generate condensable organic products in amounts comparable to the aerosol observed in Mexico City; (ii) to identify the major chemical species contributing to the aerosol; and (iii) to quantify the aerosol evolution downwind of the city. The latter two issues are in particular need of observational evaluation. The experimental detection of predicted products would provide some confirmation of the hydrocarbon oxidation pathways from specific precursors (e.g. $\delta$-hydroxy ketones from longchain alkanes). Likewise, more measurements of temporal evolution are needed to clarify the issue of ongoing regional SOA growth. If these model predictions are confirmed, useful simplifications can be derived systematically from the fully explicit chemical model (e.g. as has been done for $\mathrm{O}_{3}$ predictions by Szopa et al., 2005), and provide a physical basis for the parameterization of aerosol-related chemistry in atmospheric models.

\section{Appendix A}

\section{$\mathrm{CO}$ as a tracer of SOA production}

Several recent studies (e.g. de Gouw et al., 2008; DeCarlo et al., 2010; Kleinman et al., 2008) have sought to quantify empirically SOA production in urban outflow, by relating observed [OA] to $\triangle \mathrm{CO}$, defined as the local enhancement of $[\mathrm{CO}]$ above its background value. $\mathrm{CO}$ has a chemical loss rate of order 1 month, so has been considered to be a relatively inert tracer of urban emissions. The ratio $[\mathrm{OA}] / \Delta \mathrm{CO}$ is used to approximate the mean SOA formation rate between two points in an urban outflow plume (in the absence of significant contributions from biomass burning aerosol which has a different $\mathrm{OA} / \Delta \mathrm{CO}$ signature). Here we derive analytical solutions in terms of $\triangle \mathrm{CO}$ for the SOA mass production rate and total. Assuming $\Delta \mathrm{CO}$ is completely conserved, it may be used as a surrogate to describe the effects of $k_{\text {dil }}$ and $t$, neither of which is easily observed:

$$
\begin{aligned}
& \frac{d \Delta \mathrm{CO}}{d t} \approx-d_{\text {dil }}(\Delta \mathrm{CO}) \\
& \frac{\Delta \mathrm{CO}_{0}}{\Delta \mathrm{CO}_{t}} \approx e^{t k_{\mathrm{dil}}}
\end{aligned}
$$

Note that in this case, $k_{\text {dil }}$ represents the mean dilution rate during transit time $t$. Substitution into Eq. (6) yields $Q^{\prime}$, the SOA mass production rate approximated using $\triangle \mathrm{CO}$, with units $\mu \mathrm{g} \mathrm{d}^{-1} \mathrm{~m}_{0}^{-3}$ :

$$
\begin{aligned}
& Q^{\prime}(t)=\Delta \mathrm{CO}_{0}\left(\frac{1}{\Delta \mathrm{CO}_{t}} d[\mathrm{SOA}] d t-\frac{[\mathrm{SOA}]_{t}}{\Delta \mathrm{CO}_{t}^{2}} d \Delta \mathrm{CO} d t\right) \\
& =\Delta \mathrm{CO}_{0} \frac{d\left(\frac{[\mathrm{SOA}]}{\Delta \mathrm{CO}}\right)}{d t}
\end{aligned}
$$

Similarly, the dispersed SOA mass may be approximated from Eq. (5) in terms of [SOA] and $\triangle \mathrm{CO}$, with units of $\mu \mathrm{g} \mathrm{m}_{0}^{-3}$ :

$Q_{t}=\Delta \mathrm{CO}_{0}\left(\frac{[\mathrm{SOA}]}{\Delta \mathrm{CO}}\right)_{t}$

Figure 11 shows generally close correspondence between $Q^{\prime}$ and $M^{\prime}$ and between $Q$ and $M$, confirming the usefulness of $\mathrm{OA} / \triangle \mathrm{CO}$ as an observational tool to describe SOA formation in urban outflow, at least while $\Delta \mathrm{CO}$ is large. The CO-derived estimates of $Q$ underestimate $M$ by up to $11 \%$, reflecting active photochemistry including photolysis of carbonyl species leading to $\mathrm{CO}$ formation. The discrepancies reverse strongly during the third outflow day, with positive $Q^{\prime}$ and increasing $Q$ despite evaporative losses of SOA. This is because the urban outflow is by this point so dilute, and [CO] is so close to background values, that the dilution-induced rate of change of $\mathrm{CO}$ is similar to its photochemical loss rate so the assumption of $\mathrm{CO}$ conservation is no longer a good approximation. It is also around this time that BGOA overtakes SOA as the dominant component in our modeled aerosol (see Fig. 10). Thus, while the SOA continues to grow and evolve, as shown by the continued increase of $M$, its signature becomes increasingly difficult to separate observationally from that of the regional background.

Model $\mathrm{SOA} / \triangle \mathrm{CO}$ (Fig. 11b) within the city is $15.5 \mu \mathrm{g} \mathrm{m}^{-3} \mathrm{ppmv}^{-1}$ (or $22 \mu \mathrm{g} \mathrm{sm}^{-3} \mathrm{ppmv}^{-1}$, expressed relative to standard temperature and pressure), growing to $52 \mu \mathrm{g} \mathrm{m}^{-3} \mathrm{ppmv}^{-1} \quad\left(71 \mu \mathrm{g} \mathrm{sm}^{-3} \mathrm{ppmv}^{-1}\right)$ by daybreak on the third day of outflow. $\mathrm{OA} / \Delta \mathrm{CO}$ is generally $\sim 3 \mu \mathrm{g} \mathrm{m}^{-3} \mathrm{ppmv}^{-1}$ greater. Our ratios in the outflow are comparable to aircraft-based observations (DeCarlo et al., 2008), which find $\mathrm{OA} / \Delta \mathrm{CO}$ increasing from $40 \mu \mathrm{g} \mathrm{sm}^{-3} \mathrm{ppmv}^{-1}$ above the city to 70 to $90 \mathrm{\mu g} \mathrm{sm}^{-3} \mathrm{ppmv}^{-1}$ in aged air. The aging timescale of $\sim 1$ photochemical day assigned to the observed growth is, however, somewhat faster than in our model, which takes almost two days for a similar $\mathrm{OA} / \Delta \mathrm{CO}$ increase. 
Acknowledgements. J. Lee-Taylor was supported and SM was supported in part by a grant from the US Department of Energy, Office of Science, BER, DE-FG02-ER63993. We gratefully acknowledge discussions with J. Jimenez (University of Colorado, Boulder), Paul Ziemann (University of California, Riverside), and Andrew Conley (NCAR). The National Center for Atmospheric Research is sponsored by the National Science Foundation.

Edited by: G. McFiggans

\section{References}

Aiken, A. C., Decarlo, P. F., Kroll, J. H., Worsnop, D. R., Huffman, J. A., Docherty, K. S., Ulbrich, I. M., Mohr, C., Kimmel, J. R., Sueper, D., Sun, Y., Zhang, Q., Trimborn, A., Northway, M., Ziemann, P. J., Canagaratna, M. R., Onasch, T. B., Alfarra, M. R., Prevot, A. S. H., Dommen, J., Duplissy, J., Metzger, A., Baltensperger, U. and Jimenez, J. L.: O/C and OM/OC ratios of primary, secondary, and ambient organic aerosols with highresolution time-of-flight aerosol mass spectrometry, Environ. Sci. Technol., 42, 4478-4485, doi:10.1021/es703009q, 2008.

Aiken, A. C., Salcedo, D., Cubison, M. J., Huffman, J. A., DeCarlo, P. F., Ulbrich, I. M., Docherty, K. S., Sueper, D., Kimmel, J. R., Worsnop, D. R., Trimborn, A., Northway, M., Stone, E. A., Schauer, J. J., Volkamer, R. M., Fortner, E., de Foy, B., Wang, J., Laskin, A., Shutthanandan, V., Zheng, J., Zhang, R., Gaffney, J., Marley, N. A., Paredes-Miranda, G., Arnott, W. P., Molina, L. T., Sosa, G., and Jimenez, J. L.: Mexico City aerosol analysis during MILAGRO using high resolution aerosol mass spectrometry at the urban supersite (T0) Part 1: Fine particle composition and organic source apportionment, Atmos. Chem. Phys., 9, 66336653, doi:10.5194/acp-9-6633-2009, 2009.

Apel, E. C., Emmons, L. K., Karl, T., Flocke, F., Hills, A. J., Madronich, S., Lee-Taylor, J., Fried, A., Weibring, P., Walega, J., Richter, D., Tie, X., Mauldin, L., Campos, T., Weinheimer, A., Knapp, D., Sive, B., Kleinman, L., Springston, S., Zaveri, R., Ortega, J., Voss, P., Blake, D., Baker, A., Warneke, C., Welsh-Bon, D., de Gouw, J., Zheng, J., Zhang, R., Rudolph, J., Junkermann, W., and Riemer, D. D.: Chemical evolution of volatile organic compounds in the outflow of the Mexico City Metropolitan area, Atmos. Chem. Phys., 10, 2353-2375, doi:10.5194/acp-10-23532010, 2010.

Aumont, B., Madronich, S., Bey, I., and Tyndall, G. S.: Contribution of secondary VOC to the composition of aqueous atmospheric particles: A modeling approach, J. Atmos. Chem., 35, 59-75, doi:10.1023/A:1006243509840, 2000.

Aumont, B., Szopa, S., and Madronich, S.: Modelling the evolution of organic carbon during its gas-phase tropospheric oxidation: development of an explicit model based on a self generating approach, Atmos. Chem. Phys., 5, 2497-2517, doi:10.5194/acp-52497-2005, 2005.

Aumont, B., Camredon, M., Valorso, R., Lee-Taylor, J., and Madronich, S.: Development of Systematic Reduction Techniques to Describe the SOA/VOC/NO $/ \mathrm{O}_{3}$ System, in: Atmospheric Chemical Mechanisms Conference, Air Quality Research Center, UC Davis, CA, 10-12 December, 2008.

Barley, M. H. and McFiggans, G.: The critical assessment of vapor pressure estimation methods for use in modelling the formation of atmospheric organic aerosol, Atmos. Chem. Phys., 10, 749767, doi:10.5194/acp-10-749-2010, 2010.

Barsanti, K. C. and Pankow, J. F.: Thermodynamics of the formation of atmospheric organic particulate matter by accretion reactions - Part 1: aldehydes and ketones, Atmos. Environ., 38, 4371-4382, doi:10.1016/j.atmosenv.2004.03.035, 2004.

Bessagnet, B., Seigneur, C., and Menut, L.: Impact of dry deposition of semi-volatile organic compounds on secondary organic aerosols, Atmos. Environ., 44, 1781-1787, doi:10.1016/j.atmosenv.2010.01.027, 2010.

Blake, D. R. and Rowland, F. S.: Urban Leakage of Liquefied Petroleum Gas and its Impact on Mexico-City Air-Quality, Science, 269, 953-956, doi:10.1126/science.271.5252.1041, 1995.

Blando, J. D. and Turpin, B. J.: Secondary organic aerosol formation in cloud and fog droplets: a literature evaluation of plausibility, Atmos. Environ., 34, 1623-1632, doi:10.1016/S13522310(99)00392-1, 2000.

Bloss, C., Wagner, V., Bonzanini, A., Jenkin, M. E., Wirtz, K., Martin-Reviejo, M., and Pilling, M. J.: Evaluation of detailed aromatic mechanisms (MCMv3 and MCMv3.1) against environmental chamber data, Atmos. Chem. Phys., 5, 623-639, doi:10.5194/acp-5-623-2005, 2005a.

Bloss, C., Wagner, V., Jenkin, M. E., Volkamer, R., Bloss, W. J., Lee, J. D., Heard, D. E., Wirtz, K., Martin-Reviejo, M., Rea, G., Wenger, J. C., and Pilling, M. J.: Development of a detailed chemical mechanism (MCMv3.1) for the atmospheric oxidation of aromatic hydrocarbons, Atmos. Chem. Phys., 5, 641-664, doi:10.5194/acp-5-641-2005, 2005b.

Bruns, E. A., Perraud, V., Zelenyuk, A., Ezell, M. J., Johnson, S. N., Yu, Y., Imre, D., Finlayson-Pitts, B. J., and Alexander, M. L.: Comparison of FTIR and particle mass spectrometry for the measurement of articulate organic nitrates, Environ. Sci. Technol., 44, 1056-1061, doi:10.1021/es9029864, 2010.

CAM: Inventario de emisiones a la atmósfera, Zona Metropolitana del Valle de México 2004, Comisión Ambiental Metropolitana, Mexico, 2006.

Camredon, M. and Aumont, B.: Assessment of vapor pressure estimation methods for secondary organic aerosol modeling, Atmos. Environ., 40, 2105-2116, doi:10.1016/j.atmosenv.2005.11.051, 2006.

Camredon, M., Aumont, B., Lee-Taylor, J., and Madronich, S.: The SOA/VOC/NOx system: an explicit model of secondary organic aerosol formation, Atmos. Chem. Phys., 7, 5599-5610, doi:10.5194/acp-7-5599-2007, 2007.

Castro, T., Madronich, S., Rivale, S., Muhila, A., and Mar, B.: The influence of aerosols on photochemical smog in Mexico City, Atmos. Environ., 35, 1765-1772, doi:10.1016/S13522310(00)00449-0, 2001.

Chan, A. W. H., Kautzman, K. E., Chhabra, P. S., Surratt, J. D., Chan, M. N., Crounse, J. D., Krten, A., Wennberg, P. O., Flagan, R. C., and Seinfeld, J. H.: Secondary organic aerosol formation from photooxidation of naphthalene and alkylnaphthalenes: implications for oxidation of intermediate volatility organic compounds (IVOCs), Atmos. Chem. Phys., 9, 3049-3060, doi:10.5194/acp-9-3049-2009, 2009.

Claeys, M., Graham, B., Vas, G., Wang, W., Vermeylen, R., Pashynska, V., Cafmeyer, J., Guyon, P., Andreae, M. O., Artaxo, P., and Maenhut, W.: Formation of secondary organic aerosols through photooxidation of isoprene, Science, 303, 1173-1176, 
doi:10.1126/science.1092805, 2004.

Clegg, S. L., Seinfeld, J. H., and Brimblecombe, P.: Thermodynamic modelling of aqueous aerosols containing electrolytes and dissolved organic compounds, J. Aerosol Sci., 32, 713-738, doi:10.1016/S0021-8502(00)00105-1, 2001.

Coe, H., Allan, J. D., Alfarra, M. R., Bower, K. N., Flynn, M. J., McFiggans, G. B., Topping, D. O., Williams, P. I., O'Dowd, C. D., Dall'Osto, M., Beddows, D. C. S., and Harrison, R. M.: Chemical and physical characteristics of aerosol particles at a remote coastal location, Mace Head, Ireland, during NAMBLEX, Atmos. Chem. Phys., 6, 3289-3301, doi:10.5194/acp-6-32892006, 2006

Corr, C. A., Krotkov, N., Madronich, S., Slusser, J. R., Holben, B., Gao, W., Flynn, J., Lefer, B., and Kreidenweis, S. M.: Retrieval of aerosol single scattering albedo at ultraviolet wavelengths at the T1 site during MILAGRO, Atmos. Chem. Phys., 9, 58135827, doi:10.5194/acp-9-5813-2009, 2009.

Day, D. A., Liu, S., Russell, L. M., and Ziemann, P. J.: Organonitrate group concentrations in submicron particles with high nitrate and organic fractions in coastal southern California, Atmos. Environ., 44, 1970-1979, doi:10.1016/j.atmosenv.2010.02.045, 2010.

de Foy, B., Varela, J. R., Molina, L. T., and Molina, M. J.: Rapid ventilation of the Mexico City basin and regional fate of the urban plume, Atmos. Chem. Phys., 6, 2321-2335, doi:10.5194/acp-6-2321-2006, 2006.

de Gouw, J. and Jimenez, J. L.: Organic Aerosols in the Earth's Atmosphere, Environ. Sci. Technol., 43, 7614-7618, doi:10.1021/es9006004, 2009

de Gouw, J. A., Brock, C. A., Atlas, E. L., Bates, T. S., Fehsenfeld, F. C., Goldan, P. D., Holloway, J. S., Kuster, W. C., Lerner, B. M., Matthew, B. M., Middlebrook, A. M., Onasch, T. B., Peltier, R. E., Quinn, P. K., Senff, C. J., Stohl, A., Sullivan, A. P., Trainer, M., Warneke, C., Weber, R. J. and Williams, E. J.: Sources of particulate matter in the northeastern United States in summer: 1. Direct emissions and secondary formation of organic matter in urban plumes, J. Geophys. Res.-Atmos., 113, D08301, doi:10.1029/2007JD009243, 2008.

DeCarlo, P. F., Dunlea, E. J., Kimmel, J. R., Aiken, A. C., Sueper, D., Crounse, J., Wennberg, P. O., Emmons, L., Shinozuka, Y., Clarke, A., Zhou, J., Tomlinson, J., Collins, D. R., Knapp, D., Weinheimer, A. J., Montzka, D. D., Campos, T., and Jimenez, J. L.: Fast airborne aerosol size and chemistry measurements above Mexico City and Central Mexico during the MILAGRO campaign, Atmos. Chem. Phys., 8, 4027-4048, doi:10.5194/acp8-4027-2008, 2008.

DeCarlo, P. F., Ulbrich, I. M., Crounse, J., de Foy, B., Dunlea, E. J., Aiken, A. C., Knapp, D., Weinheimer, A. J., Campos, T., Wennberg, P. O., and Jimenez, J. L.: Investigation of the sources and processing of organic aerosol over the Central Mexican Plateau from aircraft measurements during MILAGRO, Atmos. Chem. Phys., 10, 5257-5280, doi:10.5194/acp-10-52572010, 2010.

Donahue, N. M., Robinson, A. L., Stanier, C. O., and Pandis, S. N.: Coupled partitioning, dilution, and chemical aging of semivolatile organics, Environ. Sci. Technol., 40, 2635-2643, doi:10.1021/es052297c, 2006.

Dunlea, E. J., DeCarlo, P. F., Aiken, A. C., Kimmel, J. R., Peltier, R. E., Weber, R. J., Tomlinson, J., Collins, D. R., Shinozuka,
Y., McNaughton, C. S., Howell, S. G., Clarke, A. D., Emmons, L. K., Apel, E. C., Pfister, G. G., van Donkelaar, A., Martin, R. V., Millet, D. B., Heald, C. L., and Jimenez, J. L.: Evolution of Asian aerosols during transpacific transport in INTEX-B, Atmos. Chem. Phys., 9, 7257-7287, doi:10.5194/acp-9-7257-2009, 2009.

Dusanter, S., Vimal, D., Stevens, P. S., Volkamer, R., and Molina, L. T.: Measurements of $\mathrm{OH}$ and $\mathrm{HO}_{2}$ concentrations during the MCMA-2006 field campaign - Part 1: Deployment of the Indiana University laser-induced fluorescence instrument, Atmos. Chem. Phys., 9, 1665-1685, doi:10.5194/acp-9-1665-2009, 2009a.

Dusanter, S., Vimal, D., Stevens, P. S., Volkamer, R., Molina, L. T., Baker, A., Meinardi, S., Blake, D., Sheehy, P., Merten, A., Zhang, R., Zheng, J., Fortner, E. C., Junkermann, W., Dubey, M., Rahn, T., Eichinger, B., Lewandowski, P., Prueger, J., and Holder, $\mathrm{H} .:$ Measurements of $\mathrm{OH}$ and $\mathrm{HO}_{2}$ concentrations during the MCMA-2006 field campaign - Part 2: Model comparison and radical budget, Atmos. Chem. Phys., 9, 6655-6675, doi:10.5194/acp-9-6655-2009, 2009b.

Dzepina, K., Volkamer, R. M., Madronich, S., Tulet, P., Ulbrich, I. M., Zhang, Q., Cappa, C. D., Ziemann, P. J., and Jimenez, J. L.: Evaluation of recently-proposed secondary organic aerosol models for a case study in Mexico City, Atmos. Chem. Phys., 9, 5681-5709, doi:10.5194/acp-9-5681-2009, 2009.

Dzepina, K., Cappa, C. D., Volkamer, R. M., Madronich, DeCarlo, P. F., Zaveri, R. A., and Jimenez, J. L.: Modeling the multiday evolution and aging of secondary organic aerosol during MILAGRO 2006, Environ. Sci. Technol., 45, 3496-3503, doi:10.1021/es103186f, 2011.

Emmons, L. K., Apel, E. C., Lamarque, J.-F., Hess, P. G., Avery, M., Blake, D., Brune, W., Campos, T., Crawford, J., DeCarlo, P. F., Hall, S., Heikes, B., Holloway, J., Jimenez, J. L., Knapp, D. J., Kok, G., Mena-Carrasco, M., Olson, J., O’Sullivan, D., Sachse, G., Walega, J., Weibring, P., Weinheimer, A., and Wiedinmyer, C.: Impact of Mexico City emissions on regional air quality from MOZART-4 simulations, Atmos. Chem. Phys., 10, 6195-6212, doi:10.5194/acp-10-6195-2010, 2010.

Ervens, B. and Volkamer, R.: Glyoxal processing by aerosol multiphase chemistry: towards a kinetic modeling framework of secondary organic aerosol formation in aqueous particles, Atmos. Chem. Phys., 10, 8219-8244, doi:10.5194/acp-10-8219-2010, 2010.

Farmer, D. K., Matsunaga, A., Docherty, K. S., Surratt, J. D., Seinfeld, J. H., Ziemann, P. J., and Jimenez, J. L.: Response of an aerosol mass spectrometer to organonitrates and organosulfates and implications for atmospheric chemistry, Proc. Natl. Acad. Sci. USA, 107, 6670-6675, doi:10.1073/pnas.0912340107, 2010.

Fast, J., Aiken, A. C., Allan, J., Alexander, L., Campos, T., Canagaratna, M. R., Chapman, E., DeCarlo, P. F., de Foy, B., Gaffney, J., de Gouw, J., Doran, J. C., Emmons, L., Hodzic, A., Herndon, S. C., Huey, G., Jayne, J. T., Jimenez, J. L., Kleinman, L., Kuster, W., Marley, N., Russell, L., Ochoa, C., Onasch, T. B., Pekour, M., Song, C., Ulbrich, I. M., Warneke, C., WelshBon, D., Wiedinmyer, C., Worsnop, D. R., Yu, X.-Y., and Zaveri, R.: Evaluating simulated primary anthropogenic and biomass burning organic aerosols during MILAGRO: implications for assessing treatments of secondary organic aerosols, Atmos. Chem. 
Phys., 9, 6191-6215, doi:10.5194/acp-9-6191-2009, 2009.

Fast, J. D., de Foy, B., Acevedo Rosas, F., Caetano, E., Carmichael, G., Emmons, L., McKenna, D., Mena, M., Skamarock, W., Tie, X., Coulter, R. L., Barnard, J. C., Wiedinmyer, C., and Madronich, S.: A meteorological overview of the MILAGRO field campaigns, Atmos. Chem. Phys., 7, 2233-2257, doi:10.5194/acp-7-2233-2007, 2007.

Finlayson-Pitts, B. J. and Pitts Jr., J. N.: Chemistry of the upper and lower atmosphere, Academic Press, San Diego, CA, and London, UK, 2000.

Forster, P. V., Ramaswany, P., Artaxo, P., Bertsen, T., Betts, R., Fahey, D. W., Haywood, J., Lean, J., Lowe, D. C., Myhre, G., Nganga, J., Prinn, R., Raga, G., Schulz, M., and Van Dorland, R.: Changes in Atmospheric Constituents and in Radiative Forcing, in: Climate Change 2007: The Physical Science Basis. Contribution of Working Group I to the Fourth Assessment Report of the Intergovernmental Panel on Climate Change, edited by: Solomon, S., Qin, D., Manning, M., Chen, Z., Marquis, M., Averyt, K. B., Tignor, M., and Hiller, H. L., Cambridge University Press, Cambridge, United Kingdom, and New York, NY, USA, 2007.

Fortner, E. C., Zheng, J., Zhang, R., Berk Knighton, W., Volkamer, R. M., Sheehy, P., Molina, L., and André, M.: Measurements of Volatile Organic Compounds Using Proton Transfer Reaction - Mass Spectrometry during the MILAGRO 2006 Campaign, Atmos. Chem. Phys., 9, 467-481, doi:10.5194/acp-9-467-2009, 2009.

Fraser, M. P., Cass, G. R., Simoneit, B. R. T., and Rasmussen, R. A.: Air quality model evaluation data for organics, 4. C-2-C-36 nonaromatic hydrocarbons, Environ. Sci. Technol., 31, 2356-2367, doi:10.1021/es960980g, 1997.

Gelencsér and Varga: Evaluation of the atmospheric significance of multiphase reactions in atmospheric secondary organic aerosol formation, Atmos. Chem. Phys., 5, 2823-2831, doi:10.5194/acp5-2823-2005, 2005.

George, I. J. and Abbatt, J. P. D.: Heterogeneous oxidation of atmospheric aerosol particles by gas-phase radicals, Nature Chem., 2, 713-722, doi:10.1038/nchem.806, 2010.

Goldstein, A. H. and Galbally, I. E.: Known and unexplored organic constituents in the earth's atmosphere, Environ. Sci. Technol., 41, 1514-1521, doi:10.1021/es072476p, 2007.

Greenberg, J. R., Guenther, A. B., and Turnipseed, A.: Tethered balloon-based soundings of ozone, aerosols, and solar radiation near Mexico City during MIRAGE-MEX, Atmos. Environ., 43, 2672-2677, doi:10.1016/j.atmosenv.2009.02.019, 2009.

Grieshop, A. P., Logue, J. M., Donahue, N. M., and Robinson, A. L.: Laboratory investigation of photochemical oxidation of organic aerosol from wood fires 1: measurement and simulation of organic aerosol evolution, Atmos. Chem. Phys., 9, 1263-1277, doi:10.5194/acp-9-1263-2009, 2009.

Griffin, R. J., Cocker, D. R., Flagan, R. C., and Seinfeld, J. H.: Organic aerosol formation from the oxidation of biogenic hydrocarbons, J. Geophys. Res.-Atmos., 104, 3555-3567, doi:10.1029/1998JD100049, 1999.

Guzman-Torres, D., Eiguren-Fernandez, A., Cicero-Fernandez, P., Maubert-Franco, M., Retama-Hernandez, A., Ramos Villegas, R., and Miguel, A. H.: Effects of meteorology on diurnal and nocturnal levels of priority polycyclic aromatic hydrocarbons and elemental and organic carbon in $\mathrm{PM}_{10}$ at a source and a re- ceptor area in Mexico City, Atmos. Environ., 43, 2693-2699, doi:10.1016/j.atmosenv.2009.03.003, 2009.

Hamilton, J. F., Webb, P. J., Lewis, A. C., Hopkins, J. R., Smith, S., and Davy, P.: Partially oxidised organic components in urban aerosol using GCXGC-TOF/MS, Atmos. Chem. Phys., 4, 12791290, doi:10.5194/acp-4-1279-2004, 2004.

Heald, C. L., Jacob, D. J., Park, R. J., Russell, L. M., Huebert, B. J., Seinfeld, J. H., Liao, H., and Weber, R. J.: A large organic aerosol source in the free troposphere missing from current models, Geophys. Res. Lett., 32, L18809, doi:10.1029/2005GL023831, 2005.

Heald, C. L., Kroll, J. H., Jimenez, J. L., Docherty, K. S., DeCarlo, P. F., Aiken, A. C., Chen, Q., Martin, S. T., Farmer, D. K., and Artaxo, P.: A simplified description of the evolution of organic aerosol composition in the atmosphere, Geophys. Res. Lett., 37, L08803, doi:10.1029/2010GL042737, 2010.

Heisler, S. L. and Friedlander, S. K.: Gas-to-particle conversion in photochemical smog: aerosol growth laws and mechanisms for organics, Atmos. Environ., 11, 157-168, doi:10.1016/00046981(77)90220-7, 1977.

Hodzic, A., Jimenez, J. L., Madronich, S., Aiken, A. C., Bessagnet, B., Curci, G., Fast, J., Lamarque, J.-F., Onasch, T. B., Roux, G., Schauer, J. J., Stone, E. A., and Ulbrich, I. M.: Modeling organic aerosols during MILAGRO: importance of biogenic secondary organic aerosols, Atmos. Chem. Phys., 9, 6949-6981, doi:10.5194/acp-9-6949-2009, 2009.

Hodzic, A., Jimenez, J. L., Madronich, S., Canagaratna, M. R., DeCarlo, P. F., Kleinman, L., and Fast, J.: Modeling organic aerosols in a megacity: potential contribution of semi-volatile and intermediate volatility primary organic compounds to secondary organic aerosol formation, Atmos. Chem. Phys., 10, 5491-5514, doi:10.5194/acp-10-5491-2010, 2010a.

Hodzic, A., Jimenez, J. L., Prévôt, A. S. H., Szidat, S., Fast, J. D., and Madronich, S.: Can 3-D models explain the observed fractions of fossil and non-fossil carbon in and near Mexico City?, Atmos. Chem. Phys., 10, 10997-11016, doi:10.5194/acp10-10997-2010, 2010b.

Jacobson, M. Z.: Isolating nitrated and aromatic aerosols and nitrated aromatic gases as sources of ultraviolet light absorption, J. Geophys. Res.-Atmos., 104, 3527-3542, doi:10.1029/1998JD100054, 1999.

Jang, M. and Kamens, R. M.: Newly characterized products and composition of secondary aerosols from the reaction of alpha-pinene with ozone, Atmos. Environ., 33, 459-474, doi:10.1016/S1352-2310(98)00222-2, 1999.

Jimenez, J. L., Canagaratna, M. R., Donahue, N. M., Prevot, A. S. H., Zhang, Q., Kroll, J. H., DeCarlo, P. F., Allan, J. D., Coe, H., Ng, N. L., Aiken, A. C., Docherty, K. S., Ulbrich, I. M., Grieshop, A. P., Robinson, A. L., Duplissy, J., Smith, J. D., Wilson, K. R., Lanz, V. A., Hueglin, C., Sun, Y. L., Tian, J., Laaksonen, A., Raatikainen, T., Rautiainen, J., Vaattovaara, P., Ehn, M., Kulmala, M., Tomlinson, J. M., Collins, D. R., Cubison, M. J., Dunlea, E. J., Huffman, J. A., Onasch, T. B., Alfarra, M. R., Williams, P. I., Bower, K., Kondo, Y., Schneider, J., Drewnick, F., Borrmann, S., Weimer, S., Demerjian, K., Salcedo, D., Cottrell, L., Griffin, R., Takami, A., Miyoshi, T., Hatakeyama, S., Shimono, A., Sun, J. Y., Zhang, Y. M., Dzepina, K., Kimmel, J. R., Sueper, D., Jayne, J. T., Herndon, S. C., Trimborn, A. M., Williams, L. R., Wood, E. C., Middlebrook, A. M., Kolb, 
C. E., Baltensperger, U., and Worsnop, D. R.: Evolution of Organic Aerosols in the Atmosphere, Science, 326, 1525-1529, doi:10.1126/science.1180353, 2009.

Joback, K. G. and Reid, R. C.: Estimation of Pure-Component Properties from Group-Contributions, Chem. Eng. Commun., 57, 233-243, 1987.

Jobson, B. T., Volkamer, R. A., Velasco, E., Allwine, G., Westberg, H., Lamb, B. K., Alexander, M. L., Berkowitz, C. M., and Molina, L. T.: Comparison of aromatic hydrocarbon measurements made by PTR-MS, DOAS and GC-FID during the MCMA 2003 Field Experiment, Atmos. Chem. Phys., 10, 1989-2005, doi:10.5194/acp-10-1989-2010, 2010.

Kanakidou, M., Seinfeld, J. H., Pandis, S. N., Barnes, I., Dentener, F. J., Facchini, M. C., Van Dingenen, R., Ervens, B., Nenes, A., Nielsen, C. J., Swietlicki, E., Putaud, J. P., Balkanski, Y., Fuzzi, S., Horth, J., Moortgat, G. K., Winterhalter, R., Myhre, C. E. L., Tsigaridis, K., Vignati, E., Stephanou, E. G., and Wilson, J.: Organic aerosol and global climate modelling: a review, Atmos. Chem. Phys., 5, 1053-1123, doi:10.5194/acp-5-1053-2005, 2005.

Karl, T., Apel, E., Hodzic, A., Riemer, D. D., Blake, D. R., and Wiedinmyer, C.: Emissions of volatile organic compounds inferred from airborne flux measurements over a megacity, Atmos. Chem. Phys., 9, 271-285, doi:10.5194/acp-9-271-2009, 2009.

Ketseridis, G., Hahn, J., Jaenicke, R., and Junge, C.: The organic constituents of atmospheric particulate matter, Atmos. Environ., 10, 603-610, doi:10/1016/0004-6981(76)90045-7 ,1976.

Kleinman, L. I., Springston, S. R., Daum, P. H., Lee, Y.-N., Nunnermacker, L. J., Senum, G. I., Wang, J., Weinstein-Lloyd, J., Alexander, M. L., Hubbe, J., Ortega, J., Canagaratna, M. R., and Jayne, J.: The time evolution of aerosol composition over the Mexico City plateau, Atmos. Chem. Phys., 8, 1559-1575, doi:10.5194/acp-8-1559-2008, 2008.

Kroll, J. H. and Seinfeld, J. H.: Chemistry of secondary organic aerosol: Formation and evolution of low-volatility organics in the atmosphere, Atmos. Environ., 42, 3593-3624, doi:10.1016/j.atmosenv.2008.01.003, 2008.

Kroll, J. H., Ng, N. L., Murphy, S. M., Flagan, R. C., and Seinfeld, J. H.: Secondary organic aerosol formation from isoprene photooxidation under high- $\mathrm{NO}_{\mathrm{x}}$ conditions, Geophys. Res. Lett., 32, L18808, doi:10.1029/2005GL023637, 2005.

Kroll, J. H., Smith, J. D., Che, D. L., Kessler, S. H., Worsnop, D. R., and Wilson, K. R.: Measurement of fragmentation and functionalization pathways in the heterogeneous oxidation of oxidized organic aerosol, Phys. Chem. Chem. Phys., 11, 8005-8014, doi:10.1039/b905289e, 2009.

Kroll, J. H., Donahue, N. M., Jimenez, J. L., Kessler, S. H., Canagaratna, M. R., Wilson, K. R., Altieri, K. E., Mazzoleni, L. R., Wozniak, A. S., Bluhm, H., Mysak, E. R., Smith, J. D., Kolb, C. E., and Worsnop, D. R.: Carbon oxidation state as a metric for describing the chemistry of atmospheric organic aerosol, Nature Chem., 3, 133-139, doi:10.1038/NCHEM.948, 2011.

Li, G., Lei, W., Zavala, M., Volkamer, R., Dusanter, S., Stevens, P., and Molina, L. T.: Impacts of HONO sources on the photochemistry in Mexico City during the MCMA-2006/MILAGO Campaign, Atmos. Chem. Phys., 10, 6551-6567, doi:10.5194/acp10-6551-2010, 2010.

Li, G., Zavala, M., Lei, W., Tsimpidi, A. P., Karydis, V. A., Pandis, S. N., Canagaratna, M. R., and Molina, L. T.: Simulations of organic aerosol concentrations in Mexico City using the WRFCHEM model during the MCMA-2006/MILAGRO campaign, Atmos. Chem. Phys., 11, 3789-3809, doi:10.5194/acp-11-37892011, 2011.

Lim, Y. B. and Ziemann, P. J.: Products and mechanisms of secondary organic aerosol formation from reactions of $n$-alkanes with $\mathrm{OH}$ radicals in the presence of $\mathrm{NO}_{\mathrm{x}}$, Environ. Sci. Technol., 39, 9229-9236, doi:10.1021/es051447g, 2005.

Lim, Y. B. and Ziemann, P. J.: Kinetics of the heterogeneous conversion of 1,4-hydroxycarbonyls to cyclic hemiacetals and dihydrofurans on organic aerosol particles, Phys. Chem. Chem. Phys., 11, 8029-8039, doi:10.1039/b904333k, 2009.

Liu, S., Takahama, S., Russell, L. M., Gilardoni, S., and Baumgardner, D.: Oxygenated organic functional groups and their sources in single and submicron organic particles in MILAGRO 2006 campaign, Atmos. Chem. Phys., 9, 6849-6863, doi:10.5194/acp9-6849-2009, 2009.

Madronich, S. and Flocke, S.: Theoretical estimation of biologically effective UV radiation at the Earth's surface, in: Solar Ultraviolet Radiation - Modeling, Measurements and Effects., edited by: Zerefos, C., Springer-Verlag, Berlin, 23-48, 1997.

Middlebrook, A. M., Murphy, D. M., and Thomson, D. S.: Observations of organic material in individual marine particles at Cape Grim during the First Aerosol Characterization Experiment (ACE 1), J. Geophys. Res.-Atmos., 103, 16475-16483, doi:10.1029/97JD03719, 1998.

Molina, L. T., Madronich, S., Gaffney, J. S., Apel, E., de Foy, B., Fast, J., Ferrare, R., Herndon, S., Jimenez, J. L., Lamb, B., Osornio-Vargas, A. R., Russell, P., Schauer, J. J., Stevens, P. S., Volkamer, R., and Zavala, M.: An overview of the MILAGRO 2006 Campaign: Mexico City emissions and their transport and transformation, Atmos. Chem. Phys., 10, 8697-8760, doi:10.5194/acp-10-8697-2010, 2010.

Morgan, W. T., Allan, J. D., Bower, K. N., Highwood, E. J., Liu, D., McMeeking, G. R., Northway, M. J., Williams, P. I., Krejci, R., and Coe, H.: Airborne measurements of the spatial distribution of aerosol chemical composition across Europe and evolution of the organic fraction, Atmos. Chem. Phys., 10, 4065-4083, doi:10.5194/acp-10-4065-2010, 2010.

Mugica, V., Hernandez, S., Torres, M., and Garcia, R.: Seasonal Variation of Polycyclic Aromatic Hydrocarbon Exposure Levels in Mexico City, J. Air Waste Manage. Assoc., 60, 548-555, doi:10.3155/1047-3289.60.5.548, 2010.

Myrdal, P. B. and Yalkowsky, S. H.: Estimating pure component vapor pressures of complex organic molecules, Ind. Eng. Chem. Res., 36, 2494-2499, doi:10.1021/ie9502421, 1997.

Ng, N. L., Kroll, J. H., Chan, A. W. H., Chhabra, P. S., Flagan, R. C., and Seinfeld, J. H.: Secondary organic aerosol formation from $m$-xylene, toluene, and benzene, Atmos. Chem. Phys., 7, 3909-3922, doi:10.5194/acp-7-3909-2007, 2007.

Odum, J. R., Hoffmann, T., Bowman, F., Collins, D., Flagan, R. C., and Seinfeld, J. H.: Gas/particle partitioning and secondary organic aerosol yields, Environ. Sci. Technol., 30, 2580-2585, doi:10.1021/es059043+, 1996.

Özel, M. Z., Ward, M. W., Hamilton, J. F., Lewis, A. C., Raventos-Duran, T., and Harrison, R. M.: Analysis of Organic Nitrogen Compounds in Urban Aerosol Samples Using GCxGC-TOF/MS, Aerosol Sci. Technol., 44, 109-116, doi:10.1080/02786820903410105, 2010. 
Orlando, J. J., Tyndall, G. S., and Wallington, T. J.: The atmospheric chemistry of alkoxy radicals, Chem. Rev., 103, 46574689, doi:10.1021/cr020527p, 2003.

Pandis, S. N., Paulson, S. E., Seinfeld, J. H., and Flagan, R. C.: Aerosol formation in the photooxidation of isoprene and betapinene, Atmos. Environ., 25A, 997-1008, doi:10.1016/09601686(91)90141-S, 1991.

Pandis, S. N., Harley, R. A., Cass, G. R., and Seinfeld, J. H.: Secondary organic aerosol formation and transport, Atmos. Environ., 26A, 2269-2282, doi:10.1016/0960-1686(92)90358-R, 1992.

Pankow, J. F.: An Absorption-Model of Gas-Particle Partitioning of Organic Compounds in the Atmosphere, Atmos. Environ., 28, 185-188, doi:10.1016/1352-2310(94)90093-9, 1994a.

Pankow, J. F.: An Absorption-Model of the Gas Aerosol Partitioning Involved in the Formation of Secondary Organic Aerosol, Atmos. Environ., 28, 189-193, doi:10.1016/1352-2310(94)900949, 1994b.

Pankow, J. F., Seinfeld, J. H., Asher, W. E., and Erdakos, G. B.: Modeling the formation of secondary organic aerosol, 1. Application of theoretical principles to measurements obtained in the alpha-pinene/, beta- pinene/, sabinene/, Delta(3)-carene/, and cyclohexene/ozone systems, Environ. Sci. Technol., 35, 11641172, doi:10.1021/es001321d, 2001.

Pope, C. A. and Dockery, D. W.: Health effects of fine particulate air pollution: Lines that connect, J. Air Waste Manage. Assoc., 56, 709-742, 2006.

Presto, A. A., Miracolo, M. A., Kroll, J. H., Worsnop, D. R., Robinson, A. L., and Donahue, N. M.: Intermediatevolatility organic compounds: a potential source of ambient oxidized organic aerosol, Environ. Sci. Technol., 43, 4744-4749, doi:10.1021/es803219q, 2009.

Presto, A. A., Miracolo, M. A., Donahue, N. M., and Robinson, A. L.: Secondary organic aerosol formation from high- $\mathrm{NO}_{\mathrm{x}}$ photooxidation of low-volatility precursors: $n$-alkanes, Environ. Sci. Technol., 44, 2029-2034, doi:10.1021/es903712r, 2010.

Pun, B. K. and Seigneur, C.: Investigative modeling of new pathways for secondary organic aerosol formation, Atmos. Chem. Phys., 7, 2199-2216, doi:10.5194/acp-7-2199-2007, 2007.

Red de Meteorología y Radiación Solar, REDMET, available at: http://www.smadf.gob.mx/simat2/ SistemadeMonitoreoAtmosferico, SIMAT, last access: March, 2009.

Rickard, A. R., Wyche, K. P., Metzger, A., Monks, P. S., Ellis, A. M., Dommen, J., Baltensperger, U., Jenkin, M. E., and Pilling, M. J.: Gas phase precursors to anthropogenic secondary organic aerosol: using the Master Chemical Mechanism to probe detailed observations of 1,3,5-trimethylbenzene photo-oxidation, Atmos. Environ., 44, 5423-5433, doi:10.1016/j.atmosenv.2009.09.043, 2010.

Robinson, A. L., Donahue, N. M., Shrivastava, M. K., Weitkamp, E. A., Sage, A. M., Grieshop, A. P., Lane, T. E., Pierce, J. R., and Pandis, S. N.: Rethinking organic aerosols: Semivolatile emissions and photochemical aging, Science, 315, 1259-1262, doi:10.1126/science.1133061, 2007.

Rosenfeld, D., Lohmann, U., Raga, G. B., O’Dowd, C. D., Kulmala, M., Fuzzi, S., Reissell, A., and Andreae, M. O.: Flood or drought: How do aerosols affect precipitation?, Science, 321, 1309-1313, doi:10.1126/science.1160606, 2008.
Russell, L. M., Bahadur, R., and Ziemann, P. J.: Identifying organic aerosol sources by comparing functional group composition in chamber and atmospheric particles, Proc. Natl. Acad. Sci. USA, 108, 3516-3521, doi:10.1073/pnas.1006461108, 2011.

Shakya, K. M. and Griffin, R. J.: Secondary Organic Aerosol from Photooxidation of Polycyclic Aromatic Hydrocarbons, Environ. Sci. Technol., 44, 8134-8139, doi:10.1021/es1019417, 2010.

Shaw, W. J., Pekour, M. S., Coulter, R. L., Martin, T. J., and Walters, J. T.: The daytime mixing layer observed by radiosonde, profiler, and lidar during MILAGRO, Atmos. Chem. Phys. Discuss., 7, 15025-15065, doi:10.5194/acpd-7-15025-2007, 2007.

Shon, Z.-H., Madronich, S., Song, S.-K., Flocke, F. M., Knapp, D. J., Anderson, R. S., Shetter, R. E., Cantrell, C. A., Hall, S. R., and Tie, X.: Characteristics of the NO-NO $2-\mathrm{O}_{3}$ system in different chemical regimes during the MIRAGE-Mex field campaign, Atmos. Chem. Phys., 8, 7153-7164, doi:10.5194/acp-8-7153-2008, 2008.

Stockwell, W. R., Kirchner, F., Kuhn, M., and Seefeld, S.: A new mechanism for regional atmospheric chemistry modeling, J. Geophys. Res.-Atmos., D-22, 25847-25879, doi:10.1029/97JD00849, 1997.

Sun, J. Y., Zhang, Q., Canagaratna, M. R., Zhang, Y. M., Ng, N. L., Sun, Y. L., Jayne, J. T., Zhang, X. C., Zhang, X. Y., and Worsnop, D. R.: Highly time- and size-resolved characterization of submicron aerosol particles in Beijing using an Aerodyne Aerosol Mass Spectrometer, Atmos. Environ., 44, 131-140, doi:10.1016/j.atmosenv.2009.03.020, 2010.

Szopa, S., Aumont, B., and Madronich, S.: Assessment of the reduction methods used to develop chemical schemes: building of a new chemical scheme for VOC oxidation suited to threedimensional multiscale $\mathrm{HO}_{\mathrm{x}}-\mathrm{NO}_{\mathrm{x}}$-VOC chemistry simulations, Atmos. Chem. Phys., 5, 2519-2538, doi:10.5194/acp-5-25192005, 2005.

Thompson, A. M., Yorks, J. E., Miller, S. K., Witte, J. C., Dougherty, K. M., Morris, G. A., Baumgardner, D., Ladino, L., and Rappenglück, B.: Tropospheric ozone sources and wave activity over Mexico City and Houston during MILAGRO/Intercontinental Transport Experiment (INTEX-B) Ozonesonde Network Study, 2006 (IONS-06), Atmos. Chem. Phys., 8, 5113-5125, doi:10.5194/acp-8-5113-2008, 2008.

Tie, X., Madronich, S., Li, G., Ying, Z., Weinheimer, A., Apel, E., and Campos, T.: Simulation of Mexico City plumes during the MIRAGE-Mex field campaign using the WRF-Chem model, Atmos. Chem. Phys., 9, 4621-4638, doi:10.5194/acp-9-4621-2009, 2009.

Tsimpidi, A. P., Karydis, V. A., Zavala, M., Lei, W., Molina, L., Ulbrich, I. M., Jimenez, J. L., and Pandis, S. N.: Evaluation of the volatility basis-set approach for the simulation of organic aerosol formation in the Mexico City metropolitan area, Atmos. Chem. Phys., 10, 525-546, doi:10.5194/acp-10-525-2010, 2010.

Turpin, B. J., Huntzicker, J. J., Larson, S. M., and Cass, G. R.: Los-Angeles summer midday particulate carbon - primary and secondary aerosol, Environ. Sci. Technol., 25, 1788-1793, doi:10.1021/es00022a017, 1991.

Valorso, R., Aumont, B., Camredon, M., Raventos-Duran, T., Mouchel-Vallon, C., Ng, N. L., Seinfeld, J. H., Lee-Taylor, J., and Madronich, S.: Explicit modelling of SOA formation from $\alpha$-pinene photooxidation: sensitivity to vapor pressure estimation, Atmos. Chem. Phys., 11, 6895-6910, doi:10.5194/acp-11- 
6895-2011, 2011.

Verwer, J. G.: Gauss-Seidel iteration for stiff ODEs from chemical kinetics, SIAM J. Sci. Computing, 15, 1243-1250 1994.

Verwer, J. G., Blom, J. G., Van Loon, M., and Spee, E. J.: A comparison of stiff ODE solvers for atmospheric chemistry problems, Atmos. Environ., 30, 49-58, doi:10.1016/1352-2310(95)00283$5,1996$.

Volkamer, R., Jimenez, J. L., San Martini, F., Dzepina, K., Zhang, Q., Salcedo, D., Molina, L. T., Worsnop, D. R., and Molina, M. J.: Secondary organic aerosol formation from anthropogenic air pollution: Rapid and higher than expected, Geophys. Res. Lett., 33, L17811, doi:10.1029/2006GL026899, 2006.

Williams, B. J., Goldstein, A. H., Kreisberg, N. M., and Hering, S. V.: In situ measurements of gas/particle transitions for atmospheric semivolatile organic compounds, Proc. Natl. Acad. Sci. USA, 107, 6676-6681, doi:10.1073/pnas.0911858107, 2010.
Zhang, Q., Worsnop, D. R., Canagaratna, M. R., and Jimenez, J. L.: Hydrocarbon-like and oxygenated organic aerosols in Pittsburgh: insights into sources and processes of organic aerosols, Atmos. Chem. Phys., 5, 3289-3311, doi:10.5194/acp-5-32892005, 2005.

Zhang, Q., Jimenez, J. L., Canagaratna, M. R., Allan, J. D., Coe, H., Ulbrich, I., Alfarra, M. R., Takami, A., Middlebrook, A. M., Sun, Y. L., Dzepina, K., Dunlea, E., Docherty, K., DeCarlo, P. F., Salcedo, D., Onasch, T., Jayne, J. T., Miyoshi, T., Shimono, A., Hatakeyama, S., Takegawa, N., Kondo, Y., Schneider, J., Drewnick, F., Borrmann, S., Weimer, S., Demerjian, K., Williams, P., Bower, K., Bahreini, R., Cottrell, L., Griffin, R. J., Rautiainen, J., Sun, J. Y., Zhang, Y. M., and Worsnop, D. R.: Ubiquity and dominance of oxygenated species in organic aerosols in anthropogenically-influenced Northern Hemisphere midlatitudes, Geophys. Res. Lett., 34, L13801, doi:10.1029/2007GL029979, 2007. 